\title{
Early Devonian ammonoid faunas in the Zeravshan Mountains (Uzbekistan and Tadjikistan) and the transition from a carbonate platform setting to pelagic sedimentation
}

\author{
Carole Naglik, Kenneth De Baets \& Christian Klug
}

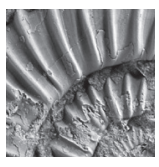

\begin{abstract}
Thick Early Devonian carbonatic sedimentary successions, exposed in the Zeravshan Mountains of Uzbekistan, display a transition from a reefal to a pelagic facies. This allows us to document and analyze the history of sedimentation and changes in marine faunas of this region. The late Pragian succession of Bursykhirman Mountain is documented with the transition from platform carbonates to pelagic sediments. Lithology and microfacies through the early Emsian sedimentary sequence of two ammonoid-bearing sections were investigated with a focus on the Dzhaus Beds. In addition to this sedimentological analysis, we discuss the palaeobiogeographically peculiar situation of Uzbekistan (palaeocontinent Kazakhstania). Many species found in the Kitab State Geological Reserve are endemic and at least restricted to the South Tien Shan. We suggest a moderately close relationship to southern Chinese and Vietnamese faunas, even though more palaeontological data from the latter two regions is needed for a test. We also revise the cephalopod fauna from the Kitab Reserve and introduce the following new taxa: Beckeroceras gen. nov., Uzbekisphinctes gen. nov., Ivoites meshchankinae sp. nov., Kitabobactrites salimovae gen. et sp. nov., and Metabactrites rakhmonovi sp. nov. • Key words: Pragian, Emsian, carbonate microfacies, endemism, Ammonoidea, palaeogeography.
\end{abstract}

Naglik, C., De Baets, K. \& Klug, C. 2019. Early Devonian ammonoid faunas in the Zeravshan Mountains (Uzbekistan and Tadjikistan) and the transition from a carbonate platform setting to pelagic sedimentation. Bulletin of Geosciences 94(3), 337-368 (16 figures, 2 tables). Czech Geological Survey, Prague. ISSN 1214-1119. Manuscript received August 20, 2018; accepted in revised form May 3, 2019; published online July 1, 2019; issued November 30, 2019.

Carole Naglik \& Christian Klug, Palaeontological Institute and Museum, University of Zurich, Karl Schmid-Strasse 4, CH-8006 Zurich, Switzerland; carole.meier@hotmail.com•Kenneth De Baets, GeoZentrum Nordbayern. Fachgruppe PaläoUmwelt. Universität Erlangen, Loewenichstr. 28, DE-91054 Erlangen, Germany

In Central Asia, Uzbekistan offers the rare opportunity to study the palaeontological inventory in exposures of Cambrian to Recent sediments (Kim et al. 2007). Concerning the Palaeozoic sedimentary records, the Zeravshan-Gissar Mountains located both in Uzbekistan and Tadjikistan are particularly important (Bardashev et al. 2005). There, the palaeontological record of the Palaeozoic sequence is both diverse and well preserved. In an area covering $56 \mathrm{~km}^{2}$ located about $170 \mathrm{~km}$ south-southeast of Samarkand, Ordovician to Carboniferous sediments are well exposed in a mountainous area. This area is protected since 1979 by the Uzbek government. It is known as the Kitab State Natural Reserve (Fig. 1A) and a research station (Zapovednik village) has been created in order to encourage scientific research in this region (Yolkin et al. 1997). In 2004, Uzbekistan even edited stamps depicting an outcrop of the early Emsian in the Khodzha Kurgan Gorge and the early Emsian ammonoid "Mimosphinctes" rudicostatus Bogoslovsky, 1980 (Ernst \& Klug 2011).
The Kitab area is famous for more or less continuous successions ranging from the Middle Ordovician to the early Carboniferous, with shallow water to terrigenoussiliceous carbonates in the Devonian part and only moderate tectonic disturbance according to Yolkin et al. (2008). Moreover, this area is of great importance for researchers focusing on the Early Devonian due to the presence of the Pragian-Emsian Global Boundary Stratotype Section and Point (Yolkin et al. 1997) as well as the rich cephalopod successions in much of the Emsian. The Pragian-Emsian GSSP was defined here because of the excellent conodont record in the Zinzilban Gorge. The current Pragian-Emsian GSSP marks the level where the conodont Polygnathus kitabicus appeared first (Yolkin et al. 1997), although it is currently being revised (Carls et al. 2008, Izokh et al. 2011, Kim et al. 2012). The current boundary is very close to the lithological boundary between the reefal and the pelagic facies (Kim et al. 2012). The origin of this sedimentological and palaeoecological transition is one of the 


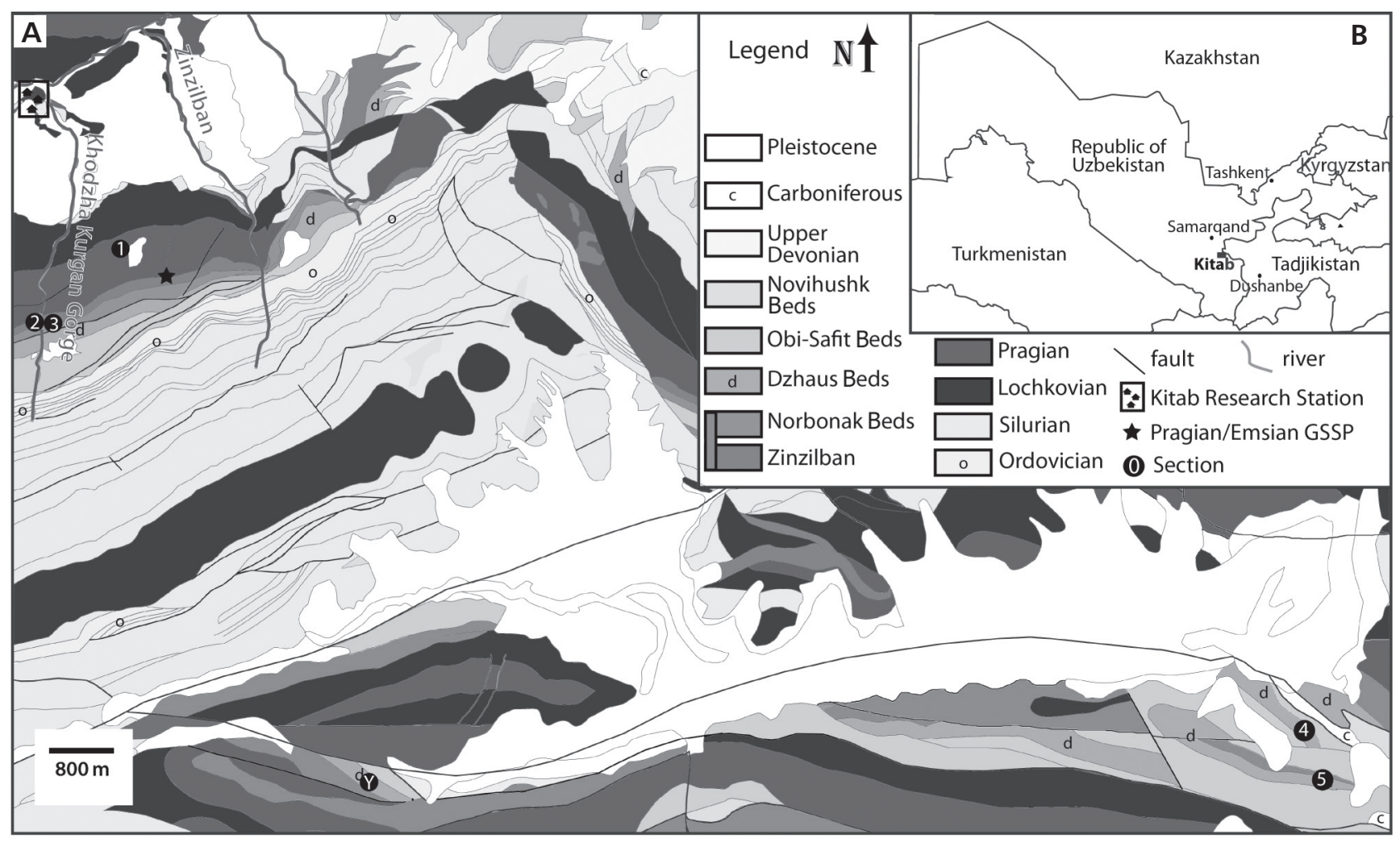

Figure 1. Maps of the study area. $\bullet$ A - location of the Kitab geological reserve in south of the Republic of Uzbekistan. $\bullet$ B - geological map of the investigated area with the studied sections: 1 - Bursykhirman; 2 - Khodzha Kurgan Gorge West of river; 3 - Khodzha Kurgan Gorge; 4 - Shirdag North; 5 - Shirdag South; Y - Yusupkul.

topics of this article as well as the changes in the ammonoid fauna during the early Emsian.

Highly diverse and abundant faunas are present in this area such as reefal asssociations of the Lochkovian and Pragian (Madmon Fm.) with tabulate corals, stromatoporoids, rugose corals, and crinoids, brachiopod associations in the latest Pragian (Zinzilban Beds, Norbonak Beds), and pelagic associations of the Emsian (Dzhaus and Obisafit Beds) with tentaculites, ammonoids, bactritids, and occasional brachiopods, orthocerids, oncocerids, trilobites, tabulate corals and bryozoans (Kim et al. 2007 and references therein, this paper).

Here, we focus on two palaeontogical aspects, namely the transition from the reefal to the pelagic associations and the pelagic facies of the Dzhaus Beds with its peculiar and highly diverse cephalopod fauna. Although the cephalopod association is overall characteristic for the early Emsian and resembles contemporary associations in, e.g. the Czech Republic (Bohemia; Chlupáč 1976; Chlupáč \& Turek 1977, 1983), China (e.g. Ruan 1981), France (Erben 1960, Lardeux et al. 1979), Germany (e.g. De Baets et al. 2009, 2013b), Morocco (Klug 2001, 2017; De Baets et al. 2010), or Russia (Bogoslovsky 1963, 1969), it contains a number of endemic taxa (some are newly described here). These cephalopods are interesting, because they comprise some of the oldest ammonoids, which occur in well-dated rocks together with bactritids, dacryoconarids and conodonts. We particularly focus on ammonoids and dacryoconarids here, as they allow a better correlation with other sections. These forms add new details to the understanding of the evolution of bactritids and early ammonoids.

The aims of this study are (1) to document the facies transition from the reefal facies of the Pragian to the pelagic facies of the early Emsian, (2) to achieve an interpretation of the events that led to these changes, (3) to document the Emsian sections of the Kitab region and their ammonoid associations including a correlation, (4) to describe new ammonoid taxa from this region and (5) to discuss the palaeogeographic relationships of the Emsian cephalopod associations of Uzbekistan with other regions.

\section{Geological setting}

The Zeravshan-Gissar Mountains of Uzbekistan and Tadjikistan are part of the South Tien Shan. The Palaeozoic and Mesozoic tectonic history of this region is highly complex. It is characterized by accretionary events of microcontinents, terranes and island arc complexes (Filippova et al. 2001, Windley et al. 2007, Brunet et al. 2017). Tectonic 
features that had developed in Central Asia already during the Hercynian orogeny occurred predominantly in zones with transitions between different facies and thus sediment types (Bardashev et al. 2005). The Tien Shan is an important orogenic system in Central Asia, which formed following the collision of the Indian and Asian plates, which began about 55-50 Ma ago (Pickering et al. 2008 and references therein).

In Uzbekistan and Tadjikistan, Devonian deposits crop out in a large area. In the Zeravshan Mountains (Khodzhakurgan and Akbasai formations), the sedimentary succession consists of pelagic to hemipelagic deep water carbonates and fine siliciclastics. Units with abundant conodonts and tentaculitids occur with cherts and volcaniclastics (Kim et al. 2007). The first outcrop we investigated is located on the Bursykhirman Mountain, which mostly consists of sediments of the Madmon Formation (late Pragian - section 1 in Fig. 1B) and the exposed sediments belong largely to the Khukarian regional Stage. It is located in the southern limb of the Dzhindzy-Darya Anticline displaying Silurian dolomites in its core and Devonian on its flanks (Yolkin et al. 2008).

In the same area, still on the southern limb of this anticline, the Kitab regional Stage crops out. It corresponds to the Emsian, which comprises the regional stratigraphic units named (from the oldest to the youngest) Zinzilban, Norbonak, Dzhaus and Obisafit Beds. There, mainly the Dzhaus Beds of two sections have been sampled and studied including the rich ammonoid occurences (sections 2 and 3 - Fig. 1B). These beds mainly consist of mostly thinbedded limestones with some chert nodules.

The Shirdag sections (sections 4 and 5 - Fig. 1B) are located in an anticline located south-west of the Sumsar Syncline, bordered by many faults, and mainly consisting of the Dzhaus Beds. Additionally, we examined a section named Yusupkul (section Y - Fig. 1B), which is also in the Shirdag area. It was studied only rarely but appears worth mentioning because of its well-preserved ammonoids (Bogoslovsky 1984).

\section{Material and methods}

We studied, measured, and sampled seven sections during two field seasons in the Kitab State Geological Reserve. Each of these sections differed in facies and topography and consequently, the quality of the exposure varied from poor to excellent. Field photos of the four main outcrops are shown in Fig. 2. Bursykhirman section starts near the top of the Madmon Formation, i.e. near the top of the Pragian carbonate platform sediments near the summit of Bursykhirman Mountain; this locality lies very close to the Pragian-Emsian GSSP in Zinzilban Gorge (Fig. 1). All the other sections were sampled only for Emsian fossils and facies. All sections were measured and sampled for palaeoenvironmental reconstructions using thin sections. Specifically, 86 thin sections were produced to investigate microfacies: 27 from the Bursykhirman section, 29 from the Khodzha Kurgan section and 30 from the Shirdag section.

Additionally, we applied the Unitary Association (UA) method (Guex \& Davaud 1984, Guex 1991, Monnet et al. 2011a, Klein \& Korn 2015) to our ammonoid dataset using the freely available software $\mathrm{PAST}^{\circledR}$ (Hammer et al. 2001). This method produces the most robust stratigraphic schemes by relying on co-occurrences of species only.

Here, we use local lithostratigraphic names. These names are used in the sense of previous authors (compare, e.g. Yolkin et al. 1997, 2008; Kim et al. 2007; Carls et al. 2008).

Most fossil specimens and the thin sections are stored at the Palaeontological Institute and Museum at the University of Zurich (PIMUZ numbers). We also refer to specimens, which are kept in Münster at the Geomuseum with the numbers B6C.52-1. Specimens that belong to the collection of the National Museum in Prague have collection numbers beginning with L (e.g. L 17716). The prefix ICh indicates that the specimens were collected by Ivo Chlupáč and are deposited in the Czech Geological Survey in Prague.

\section{Results}

\section{Bursykhirman Section (section 1 in Fig. 1B)}

This section $\left(39.173055^{\circ} \mathrm{N}, 67.261225^{\circ} \mathrm{E}\right)$ comprises $210 \mathrm{~m}$ of late Lochkovian and Pragian sediments and is depicted in Fig. 3. We started measuring the section near the summit of Bursykhirman Mountain and proceeded towards the south. The section consists predominantly of massive peloidal grainstone, floatstone and rudstone, which overlie the reef carbonates of the Madmon Formation (Lochkovian to Pragian). This section comprises older layers compared to the other studied sections and starts in the late Lochkovian (Sangitovarian Regional Stage, Pedavis pesavis conodont Zone). The first $100 \mathrm{~m}$ consist mainly of massive limestones with brachiopods, some rugose and tabulate corals (mainly favositids) and bryozoans (Fig. 3A, B, peloidal float-grainstones). At about $75 \mathrm{~m}$, a more pelagic facies rich in tentaculites [Paranowakia intermedia (Barrande, 1867)] was found (Fig. 3C) close to the Lochkovian-Pragian boundary. From about 90 to $100 \mathrm{~m}$ above base of the section, the amount of silica in the limestones and silicified reef debris increased (Fig. 3D). After $110 \mathrm{~m}$, reef debris still occur but become less abundant; this part of the section is dominated by wackestones still belongs to the Pragian (Khukarian Regional Stage). On the other hand, the silica content con- 

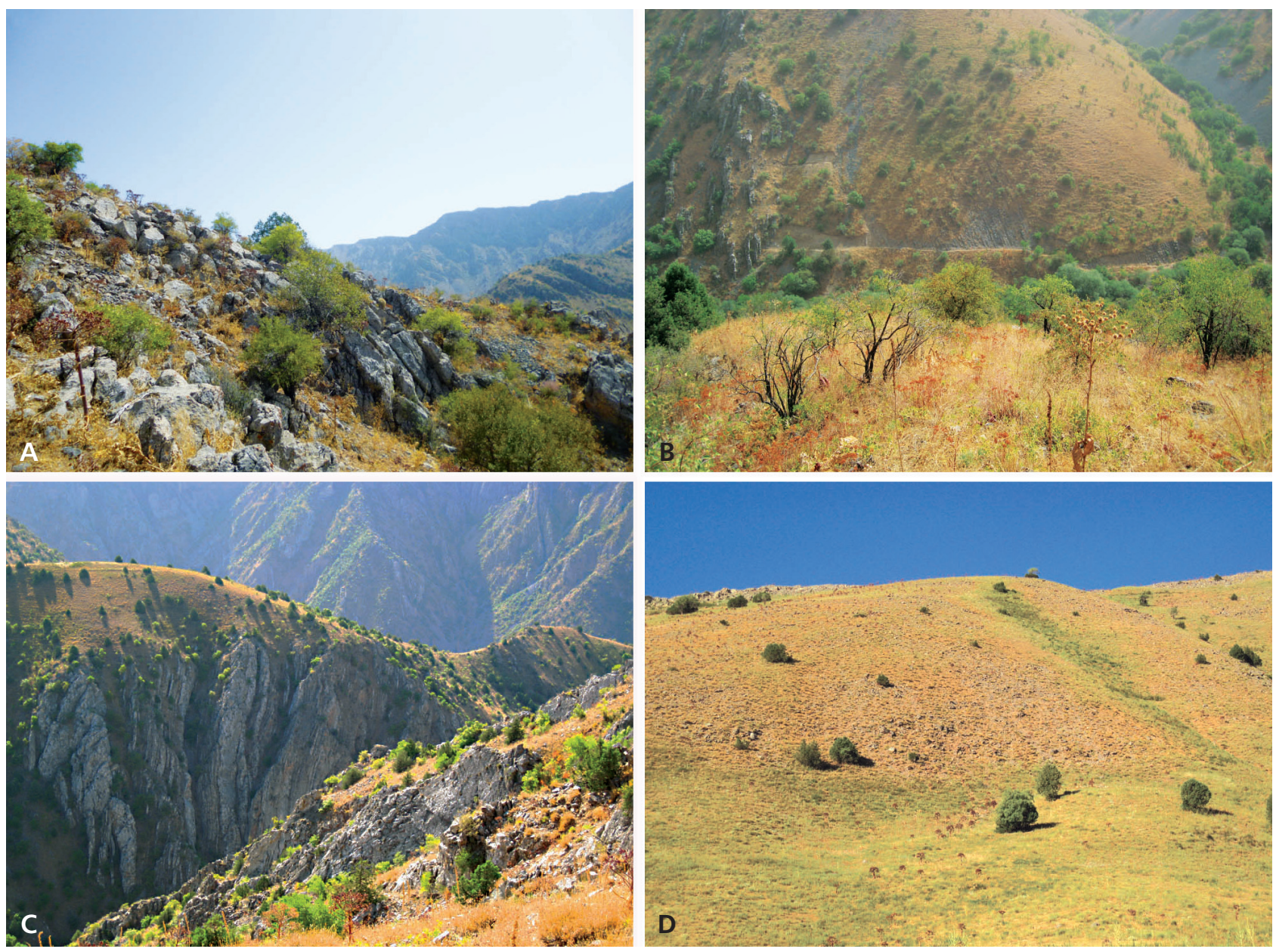

Figure 2. Parts of the main outcrops of the studied localities. $\bullet$ A - Bursykhirman, lower part of the section. $\bullet$ B - Khodzha Kurgan Gorge. C - Shirdag. D -Yusupkul, mostly covered by the vegetation, showing bad exposure to measure a section with confidence compared to the two other zones (Khodzha Kurgan Gorge and Shirdag).

tinues to increase slightly. Small ?phosphoritic concretions/ nodules occur at about $150 \mathrm{~m}$ (Fig. 3E) in a coarser microfacies, consisting predominantly of grainstones and rudstones. The top of this section consists mainly of laminated siliceous limestones rich in styliolinids and Nowakia acuaria (Richter, 1854) with some silicified reef debris (such as tabulate corals, Fig. 3F). Towards the top of this section, we found a growing amount of tectonic structures (faults, striations). The last bed included in this section is brecciated. The overlying sediments are covered by vegetation. These sediments likely consist of a more pelagic and more fine-grained facies.

\section{Khodzha Kurgan Gorge West Section (section 2 in Fig. 1B)}

This section $\left(39.166019^{\circ} \mathrm{N}, 67.248822^{\circ} \mathrm{E}\right)$ measures $30 \mathrm{~m}$ (Fig. 4) and its base corresponds to bed " $15.20 \mathrm{~m}$ " of the Khodza Kurgan Gorge section from the field excursion guidebook (Yolkin et al. 2008; see also Becker et al. 2010). Therefore, the entire section consists of the Dzhaus Beds (Kitabian Regional Stage, Linguipolygnathus inversus conodont Zone; for the conodont zonation, see Yolkin et al. 2008). It is mainly composed of massive limestone beds ( $c a .30-60 \mathrm{~cm}$ thick) alternating with thin-bedded limestones. These limestones are overall moderately rich in fauna including brachiopods, crinoids, rugose and tabulate corals. Stromatoporoids were found only once around $6 \mathrm{~m}$ above the base of the section. Ammonoids start to occur at $7.2 \mathrm{~m}$ above the base with Erbenoceras kimi Bogoslovsky, 1980 contained in a moderately thick-bedded limestone. Erbenoceras kimi is found throughout this section and often is associated with Gyroceratites laevis Eichenberg, 1931, Kimoceras lentiforme Bogoslovsky, 1980, and less frequently with Convoluticeras flexuosum Bogoslovsky, 1984. Erbenoceras advolvens (Erben, 1960) is found only once at $11 \mathrm{~m}$ above the section base, co-occurring with E. kimi, C. flexuosum and K. lentiforme. We did not sample this section for microfacies. 


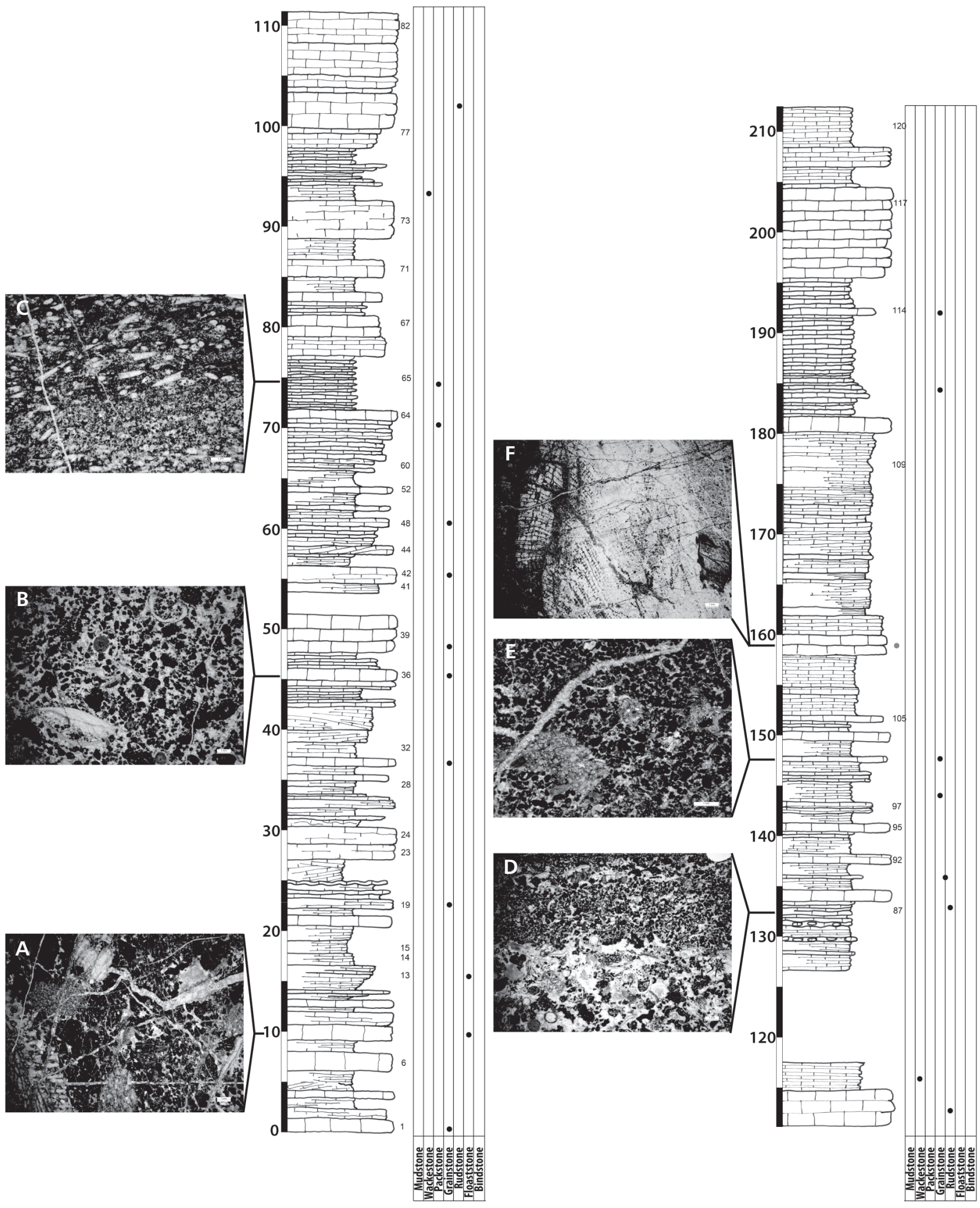

Figure 3. Bursykhirman section with indications of microfacies according to the modified Dunham classification (Dunham 1962, Embry \& Klovan 1971). Pictures illustrate the main microfacies: A - peloidal floatstone with reef debris such as bryozoans and tabulate corals, etc; B - peloidal grainstone rich in brachiopods and echinoderm debris; $\mathrm{C}$ - peloidal grainstone rich in tentaculites; D-rudstone rich in gastropods, echinoderm debris, undetermined shell debris, and probably several dasycladacean green algae; E - grainstone rich in detritic grains and some phosphoritic concretions; F - silicified reef debris, tabulate coral. 


\section{Khodzha Kurgan Gorge Section (section 3 in Fig. 1B)}

This section crops out on the east side of the river; we began measuring at the point $39.166865^{\circ} \mathrm{N}, 67.249827^{\circ} \mathrm{E}$. The section was divided into two parts, because of poor outcrop conditions between 66 to $78 \mathrm{~m}$ above the section base. Its global thickness measures about $123 \mathrm{~m}$ (Fig. 4). It starts about $29 \mathrm{~m}$ above the base of Dzhaus Beds (Kitabian, Linguipolygnathus inversus conodont Zone $=$ Stop 16 of Yolkin et al. 2008). This is probably the best section to study the sequence of early Emsian ammonoids in its stratigraphic context in Uzbekistan. The base of this section consists mainly of alternating dark limestone beds with abundant tentaculites. At about $9 \mathrm{~m}$, current-aligned tentaculites appear aligned in a thin massive packstone bed. This succession of alternating massive and thin limestone beds including black laminations goes on until about $25 \mathrm{~m}$. After $16 \mathrm{~m}$, we found the first Erbenoceras kimi. Near the base of the section, the microfacies is dominated by wackestones except for a floatstone at $6 \mathrm{~m}$ above the base. The following wackestones contain parallel, sometimes slightly wavy, thin brownish laminations. From about 23-24 $\mathrm{m}$ above the section base, orthocones occur together with Gyroceratites laevis and Erbenoceras kimi. Just after the metre 25, flattened specimens of specimens probably Convoluticeras flexuosum are present. The thickness of the following massive limestone beds slightly decreases to the metre 35. Higher up, at about $30 \mathrm{~m}$, flattened ammonoids occur abundantly in a grainstone. This grainstone contains a lot of detritic material including some questionable worm tubes. In this bed, Kitabobactrites salimovae nov. sp. is associated with Gyroceratites laevis. Above, a sequence of thin-bedded laminated wackestones follows, containing thick limestone lenses with a lateral extent of several metres; it is unclear to us whether these structures are of diagenetic or tectonic origin. At $38 \mathrm{~m}$, three-dimensionally preserved, but often fragments of ammonoids such as Uzbekisphinctes rudicostatus (Bogoslovsky, 1980) and Mimagoniatites fecundus (Barrande, 1865) were extracted from the massive limestones. In this bed, they are accompanied by orthocones, bivalves, and brachiopods. The following $7 \mathrm{~m}$-thick interval is composed of alternating thin-bedded and massive limestones, which are very poor in fossils. The massive limestone beds/banks consist of grainstone. The next ammonoid occurrence appears around $45 \mathrm{~m}$ in a massive $40 \mathrm{~cm}$-thick bed containing flattened specimens of Kitabobactrites salimovae, Gyroceratites laevis and the last occur- rence of Convoluticeras flexuosum. Concerning the microfacies, it is again dominated by wackestones. At $49 \mathrm{~m}$ above base, a $70 \mathrm{~cm}$-thick unit of thin cross-bedded limestones contains large orthocones, Gyroceratites laevis, and the last Kitabobactrites salimovae gen. et sp. nov. of this section. This unit also marks the first appearance of Ivoites meshchankinae sp. nov. in this section. After a 2 m-thick interval of limestone layers of alternating thickness with a low fossil content (no ammonoids), a $1 \mathrm{~m}$-thick and highly fossiliferous interval follows, which yielded ammonoids. The interval between 51 to $64 \mathrm{~m}$ above base yielded a highly diverse assemblage in which tabulate and rugose corals, brachiopods, dacryoconarids (probably Nowakia elegans author), crinoids, and ammonoids occur. At the base, this interval contains Erbenoceras kimi, which is the last occurrence of this species in this section. Otherwise, ammonoids of the genera Mimosphinctes, Mimagoniatites, Gyroceratites and Ivoites were found in this interval.

The last bed of this interval consists of a massive reefdebris rudstone. Above this interval, a $12.2 \mathrm{~m}$-thick interval could not be investigated because of the very poor outcrop. At around $78 \mathrm{~m}$ above base, the strata are well exposed again. From there to metre 90, an alternation of thin-bedded and massive limestones occurs with an increasing number of silicites/cherts and carbonatic nodules. Simultaneously, the fossil content decreases in abundance and diversity. These strata still contain echinoderm debris and dacryoconarids (Nowakia cancellata Lukeš, 1977) are also present. In the lower part of this interval, Uzbekisphinctes rudicostatus (Bogoslovsky, 1980) was found in association with Ivoites meshchankinae sp. nov.

The interval 90 to $103 \mathrm{~m}$ above the base consists of alternating massive and thin limestones occur with irregular surfaces, which might be interpreted as turbidites of which some might be slumped. This interval also contains some nodular beds. At $103 \mathrm{~m}$, a slight facies change is discernible. The colour of sediments turns into a darker grey and the fine-bedded intercalations become even thinner. These thin, alternating beds contain fewer fossils and accordingly no ammonoids have been found in this interval until metre 115. There, the last fossiliferous interval was found containing crinoids, bivalves, brachiopods, and the last ammonoids of the early Emsian in this section, namely Gyroceratites laevis, Uzbekisphinctes rudicostatus and Mimagoniates fecundus. The last two metres of the section correspond to the base of the Obisafit Beds and consist of a massive 2 m-thick limestone.

Figure 4. Studied sections with the accompanying fauna (main groups), the ammonoid succession, and the microfacies (Dunham classification), modified after Embry \& Klovan (1971). The UA zones are labelled on the right side and suggestions for placing the Daleje Event are marked with the grey dashed line. 


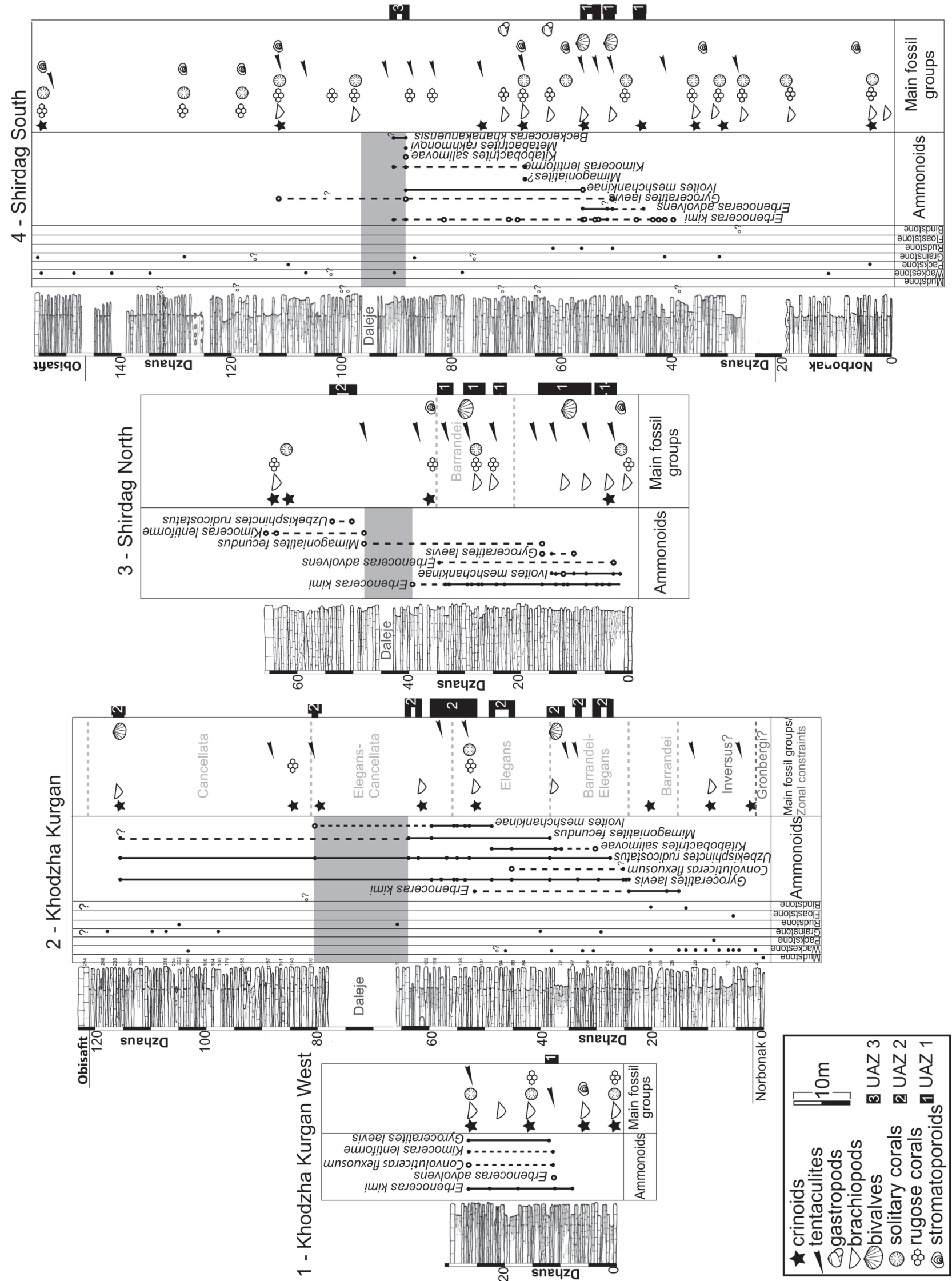




\section{Yusupkul Section (section $\mathrm{Y}$ in Fig. 1B)}

Although this area has been investigated and an about $60 \mathrm{~m}$-thick part of the section was measured (39.128883 ${ }^{\circ}$ $\mathrm{N}, 67.328448^{\circ} \mathrm{E}$ ), we do not present it here because of the poor outcrop quality (more or less dense vegetation) and the tectonic overprint that hampered the lateral correlation of beds (Figs 2-4). Nevertheless, this locality is worth mentioning as it is an interesting ammonoid locality; particularly Erbenoceras kimi and Gyroceratites laevis are common. They occur at around $20 \mathrm{~m}$ above the base of the section. Erbenoceras kimi is found first, followed by Gyroceratites laevis. Additionally, we found specimens of Gaurites sperandus Bogoslovsky, 1984. Towards the top of the section, Ivoites sp. is found associated with Erbenoceras kimi and Gyroceratites laevis. One bed was extremely rich in hatchlings of ammonoids and orthocones. As for the other sections, the facies consists mostly of alternating thin and massive thick beds of limestones containing occasionally silicified fauna such as rugose and tabulate corals, crinoids and brachiopods.

\section{Shirdag Section North (section 4 in Fig. 1B)}

The Shirdag area is located at about $12 \mathrm{~km}$ east of the Yusupkul area; we measured the section Shirdag North $\left(39.136960^{\circ} \mathrm{N}, 67.441107^{\circ} \mathrm{E}\right.$ ), which is $66 \mathrm{~m}$-thick (Fig. 4) and starts at the top of the Norbonak Beds and mainly encompasses the Dzhaus Beds. Although most of the Norbonak Beds lie in the Eolinguipolygnathus excavatus and Eol. nothoperbonus conodont zones, the uppermost part lies already in the Linguipolygnathus inversus conodont Zone (Yolkin et al. 2008). Therefore, the entire section presented here belongs to the Ling. inversus conodont Zone, since the first two recorded beds of our section correspond to the very top of the Norbonak Beds. The section starts with massive limestones with silicified reef fauna including stromatoporoids, rugose and tabulate corals, brachiopods and chert nodules. These are overlain by $4 \mathrm{~m}$ thick alternating massive dark cherty limestones and thinbedded limestones; $2.5 \mathrm{~m}$ above the base, dacryoconarids and ammonoids were found with the association of Erbenoceras kimi and Ivoites meshchankinae. Just above, Erbenoceras advolvens co-occurs with these ammonoid species. In this unit, the thickness of the beds considerably varies laterally. Massive alternating limestones and cherty layers occur until $16 \mathrm{~m}$ above the base with the repeated appearance of Gyroceratites laevis in an interval between $10 \mathrm{~m}$ to $16 \mathrm{~m}$ above base. This last occurrence coincides with the first appearance of Mimagoniatites fecundus at the base of a $6 \mathrm{~m}$-thick interval of alternating thin-bedded limestones with massive cross-bedded limestones. This interval is also marked by current-aligned dacryoconarids.
Ivoites meshchankinae sp. nov. disappears just below a horizon $20 \mathrm{~m}$ above base. Higher up, in the interval 21 to $35 \mathrm{~m}$ above base, reef debris becomes more abundant again with brachiopods (spiriferids), bivalves, rugose and tabulate corals. The dacryoconarid Nowakia barrandei also occurs in this interval. Crinoids and stromatoporoids are found near the top of this interval, which also corresponds to the last occurrence of Erbenoceras advolvens. Erbenoceras kimi is the next species to disappear at $40 \mathrm{~m}$ above base. Approximatively between 37 and $51 \mathrm{~m}$, the outcrop conditions are very poor and most is covered by scree (excavation is difficult because of the steepness of the slope). Still, $48 \mathrm{~m}$ above base, the last occurrence of Mimagoniatites fecundus was found in association with the first appearance of Kimoceras lentiforme, which ranges through to the top of the studied section (66 $\mathrm{m}$ above base). In contrast to its longer range and moderate abundance in the Khodza Kurgan area, Uzbekisphinctes rudicostatus was found here in a short interval of the section between 50 and $53 \mathrm{~m}$ above base. The last eight metres of this section consist of fine-grained cross-bedded limestones near the base, which then grade into more massive and coarsegrained limestones rich in rugose and tabulate corals as well as crinoids, associated with a few brachiopods.

\section{Shirdag section South (section 5 in Fig. 1B)}

Shirdag South section is located about $730 \mathrm{~m}$ south from the North section $\left(39.130778^{\circ} \mathrm{N}, 67.443500^{\circ} \mathrm{E}\right)$. We studied a $156 \mathrm{~m}$-thick log of the section there (Fig. 4). This section represents the longest interval of this study; it starts at the top of Norbonak Beds and the entire Dzhaus Beds are recorded. The base of Obisafit Beds is also included at the top of our section. The section starts with 5 to $6 \mathrm{~m}$-thick limestones consisting of wackestone and crinoid packstone rich in brachiopods; the limestones are often nodular and debris of reef fauna is present. This interval corresponds to the top of the Norbonak Beds. Above, there is an interval of thinner and laminated limestones containing stromatoporoids, which mark the base of the Dzhaus Beds. These laminated limestones go on until $20 \mathrm{~m}$ above base where they become more massive and the last unit is a thick bed with undulating surface, possibly representing a slump deposit. This last unit contains silicified fauna such as brachiopods, rugose and tabulate corals. After this unit, the outcrop conditions worsen and there is a gap in the section estimated to be $7.5 \mathrm{~m}$-thick. From $27 \mathrm{~m}$ above base, thicker limestone beds alternating with thin layers are cropping out, which display a rudstone and grainstone facies with abundant neritic to reef fauna: brachiopods, crinoids, tabulate corals, and dacryoconarids are common. The first occurrence of ammonoids, namely Erbenoceras kimi, is found at $40 \mathrm{~m}$ from the base of the section, corresponding to 

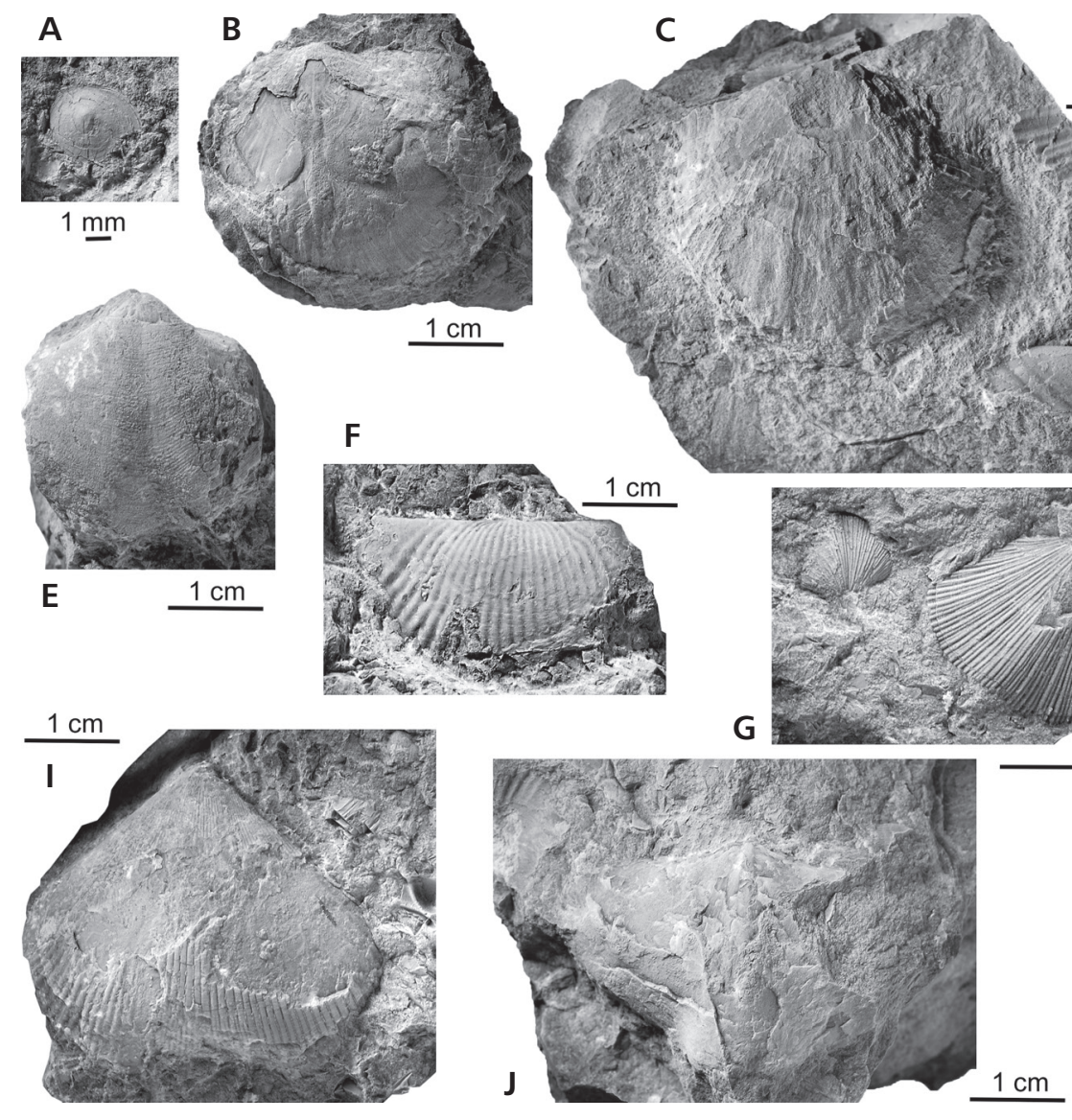

$1 \mathrm{~cm}$
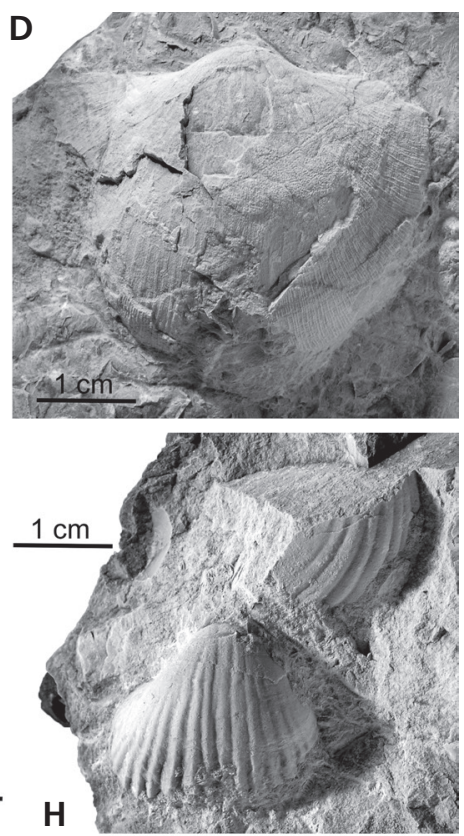

Figure 5. Brachiopods from the Early Devonian of Bursykhirman (C, G-K), Khodzha Kurgan Gorge (B, D-F), and Shirdag (A). • A - discinid inarticulate, PIMUZ 31326, Dzhaus Beds, SHK3A. - B-D - Gorgostrophia neutra (Barrande, 1848), ventral valves, Emsian; B - PIMUZ 31327, Dzhaus Beds, KKG 45; C - PIMUZ 31328, Norbonak Beds, BH79; D - PIMUZ 31329, Dzhaus Beds, KKG 237. • E - Athyridid gen et sp. indet., PIMUZ 31330, ventral valve, Dzhaus Beds, KKG 49. F - Leviconchidiella cf. gyrifera (Malygina \& Sapelnikov, 1973), PIMUZ 31331, dorsal valve, Dzhaus Beds, KKG 49. • G - Aulacella eifeliensis (Verneuil, 1850), PIMUZ 31332, dorsal valve, Dzhaus Beds, KKG 49. • H - Leviconchidiella cf. gyrifera (Malygina \& Sapelnikov, 1973), PIMUZ 31333, dorsal valve, Norbonak Beds, BH79. • I - Punctatrypa sibirica Rzhonsnitskaja, 1968, PIMUZ 31334, Dzhaus Beds, KKG 49. • J, K - Havlicekia secans (Barrande, 1848), Norbonak Beds, BH79; J - PIMUZ 31335, ventral valve; K - PIMUZ 31336, dorsal valve.

about $35 \mathrm{~m}$ from the base of the Dzhaus Beds. Erbenoceras advolvens is the second taxon found $45 \mathrm{~m}$ above the base, followed by Gyroceratites laevis at $50 \mathrm{~m}$ above base. The interval 50 to $62 \mathrm{~m}$ above base consists of thin-bedded limestones alternating with thicker massive beds than below, and the dominating microfacies consists of rudstone with brachiopods, dacryoconarids, favositids and bivalves, additionally with stromatoporoids at the top of this unit. In this interval at $56 \mathrm{~m}$, Erbenoceras advolvens is found for the last time co-occuring with the first appearance of Ivoites meshchankinae. The following $10 \mathrm{~m}$ thick interval contains brachiopods, tabulate corals and gastropods. The base of this unit shows laminations, thin siliceous beds and some thin mudstone beds without any fossils. At the top of this unit, wavy surfaces and possibly erosive surfaces are visible. Some coal debris or small driftwood pieces occur as well. At $67 \mathrm{~m}$ above base, still in this unit, Mimagoniatites sp. and Teicherticeras cf. planum Bogoslovsky, 1980 are found together with the first appearance of Kimoceras lentiforme. The section continues 72 to $88 \mathrm{~m}$ above base with massive limestones with parallel laminations alternating with thin chert layers with dominant microfacies getting a transition from rudstones to grainstones and then wackestones. This interval is less diverse in fauna, mainly with crinoids and dacryoconarids. Erbenoceras kimi is also found and tabulate corals occur near the top. At 88 to $90 \mathrm{~m}$, although there is no visible change in lithology, there is a change in ammonoid diversity. Indeed in this 2 metre-thick interval, the last occurences of the following species occur: Ivoites meshchankinae, Erbenoceras kimi and Kimoceras lentiforme. It is important to mention that in this interval, three species appear only there, namely Kitabobactrites salimovae, Metabactrites rakhmonovi and Beckeroceras khanakasuense (Yatskov, 1990). Only Gyroceratites laevis ranges through this interval and is still found later in the section until a horizon $111 \mathrm{~m}$ above base, 


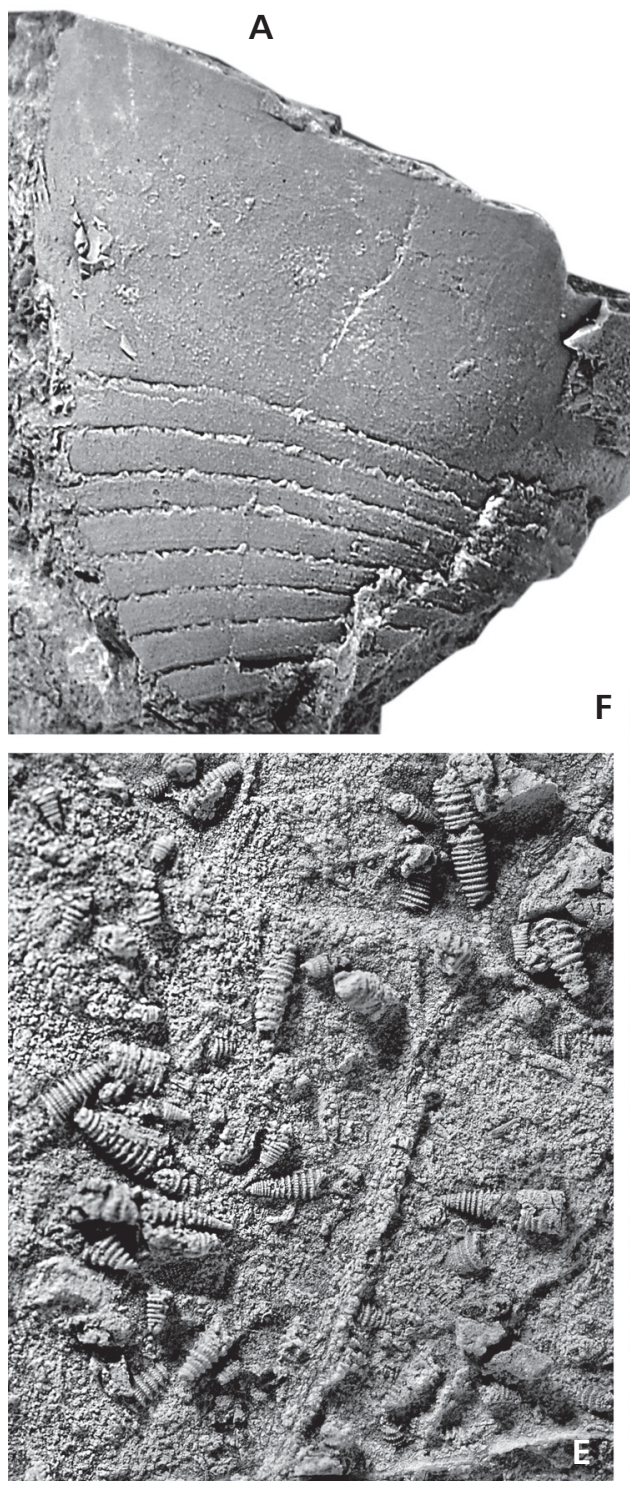

B
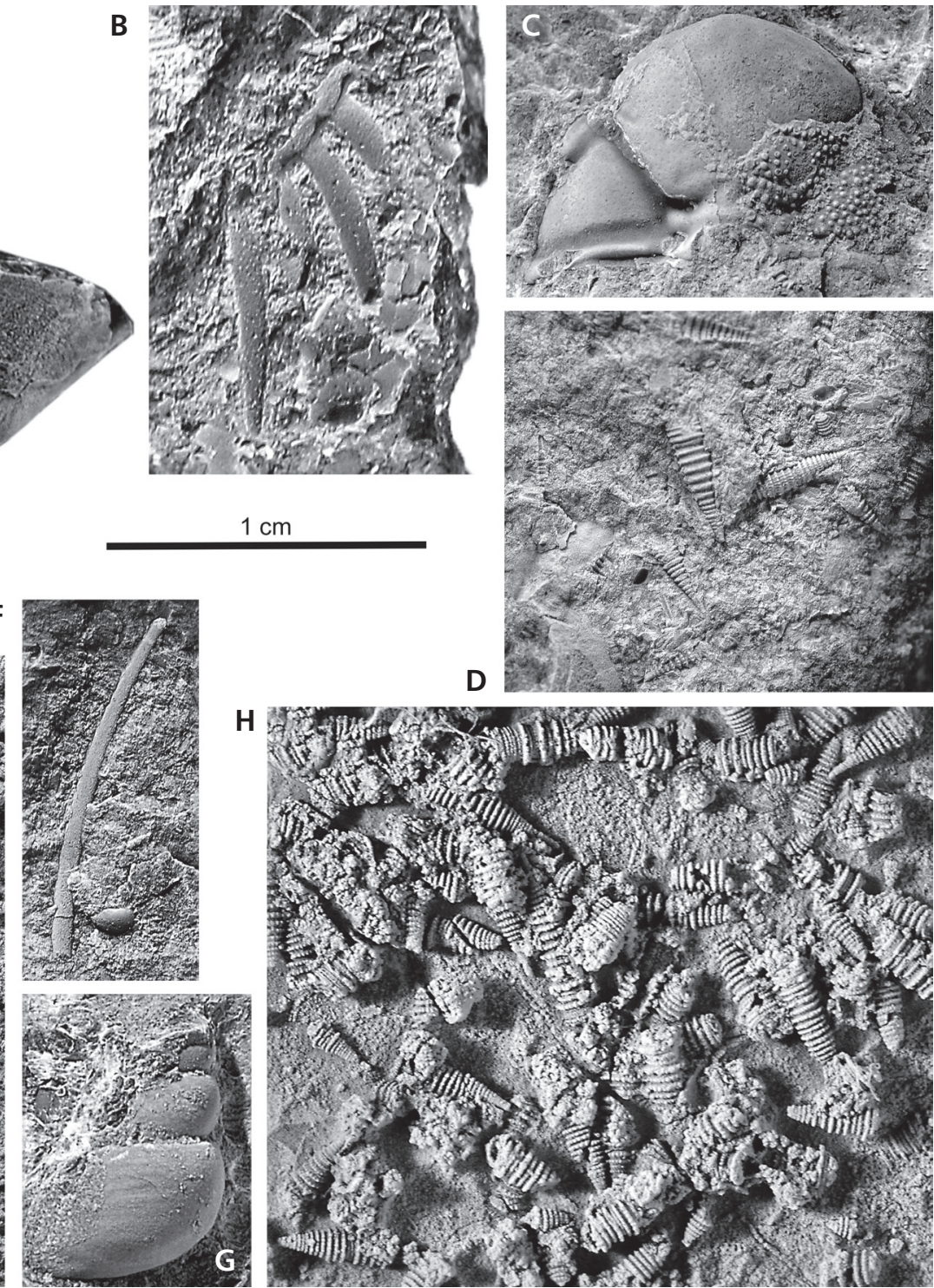

Figure 6. Diverse invertebrates from the early Emsian Dzhaus Beds. • A - Phragmoceratidae gen. et sp. indet., PIMUZ 31337, Dzhaus Beds, Khodzha Kurgan Gorge, KKG $69 \mathrm{~m}$. B - Exastipyx sp., fragmentary pygidium, associated with Metabactrites rakhmonovi sp. nov. (PIMUZ 28869), Dzhaus Beds, Yusupkul Stou, YUS01KDB. • C - Plagiolaria kitabi Crônier \& Tsmeyrek, 2010, PIMUZ 31338, Dzhaus Beds, Yusupkul Stou, YUS 01. • D, E, H - Nowakia elegans (Barrande, 1867); D - PIMUZ 31339, Dzhaus Beds, Shirdag, SHK313; E, H - PIMUZ 31340, silicified, Dzhaus Beds, from scree, Shirdag; E - PIMUZ 31340; H - PIMUZ 31341. • F - trilobite genal or pygidial spine? PIMUZ 31342, Dzhaus Beds, Shirdag, SHK 3A. • G - Gastropoda indet., PIMUZ 31343, Dzhaus Beds, Khodzha Kurgan Gorge.

which marks the last ammonoid occurrence in this section. At $94 \mathrm{~m}$, a $2.2 \mathrm{~m}$-thick interval is poorly exposed and thus could not be properly investigated. From about $96.5 \mathrm{~m}$ to $111 \mathrm{~m}$, the lithology is dominated by massive limestone beds rich in reef fauna such as tabulate corals, brachiopods, stromatoporoids and crinoids. The following unit continues until $128 \mathrm{~m}$ above base and mainly consists of over $1 \mathrm{~m}$ of thin-bedded layers with silicified beds alternating with $30-50 \mathrm{~cm}$-thick massive limestones. The top of this unit is marked by abundant reef fauna debris. From $128 \mathrm{~m}$ to the top of the section, the thin-bedded intervals decrease in thickness but the lithology still consists of alternating thin-bedded and massive layers with occasionally nodular limestone layers. Laminated wackestones are the most representative microfacies for the last part of this section. The last bed of $70 \mathrm{~cm}$ thickness is a massive reefal grainstone, which probably belongs already to the Obisafit Beds.

\section{Systematic palaeontology}

We follow the classification scheme and terminology of Korn \& Klug (2002), which was slightly modified by De Baets et al. (2013b). We use the absolute rib index or 
ARIXX ( = ribs counted within a circle centered on the midflank with the specified diameter in $\mathrm{mm}$ ) introduced by De Baets et al. (2013b).

In Figure 5, we show some brachiopods that were found in situ. Figure 6 displays some rare findings of trilobites, dacryoconarids and gastropods. Some ammonoids mentioned in the stratigraphic paragraphs above but not described in the systematic section are shown in Figs 7 and 8 .

Class Cephalopoda Cuvier, 1797

Order Bactritida Shimansky, 1951

Family Bactritidae Hyatt, 1884

\section{Genus Kitabobactrites gen. nov.}

Type species. - Kitabobactrites salimovae sp. nov.

Etymology. - After Kitab, a town in Uzbekistan, which is close to the Kitab State Geological Reserve, where the material was found.

Diagnosis. - A bactritid with a gently coiled conch. Initial shaft more strongly curved, terminal part nearly straight. Weak sculpture. Distinct ventrolateral spiral lines and ventrolateral furrow. Sutures simple with broad and moderately deep lateral lobe.

Remarks. - Becker et al. (2010) already recognized this taxon as undescribed. A main problem is that we did not manage to find a specimen that is not deformed. However, the combination of characters is so different from all other cephalopod taxa from this time interval that we confidently erect this new genus and species. As far as the conch shape is concerned, the genera Cyrtobactrites Erben, 1960, Metabactrites Bogoslovsky, 1972, Ivoites De Baets et al., 2012, and Kokenia Holzapfel, 1895 are the closest. Kokenia is Eifelian in age and thus much younger; also, it has distinct ribs. Kitabobactrites lacks such ribs, which are well developed in Ivoites and Metabactrites. These three genera occur in the same or slightly younger strata. The new genus shares the strong ventrolateral projection of Cyrtobactrites, but the latter genus has no ventrolateral furrow and rib. The coiling is actually intermediate between Cyrtobactrites and Metabactrites. It is included in the Bactritidae because it did probably not form a complete whorl and because it combines character states of growth line course and coiling mode that are unknown from ammonoids but have been documented from bactritids, namely in Cyrtobactrites (Erben 1960, Klug et al. 2008). This is of interest, because the genus shows characters typical of slightly more derived ammonoids. For example, the growth line course and presence of a ventrolateral furrow is reminiscent of Gyroceratites but the coiling
(Fig. 9) is reminiscent of a derived bactritids or of one of the first ammonoids.

Species included. - Only the type species.

Occurrence. - So far only known from the early Emsian of the Kitab State Geological Reserve (Uzbekistan).

\section{Kitabobactrites salimovae sp. nov.} Figures 9A, B, E, G; 10B

2010 Gen. aff. Cyrtobactrites n. sp. - Becker et al. 2010, p. 21, figs 2.3, 2.4.

Holotype. - PIMUZ 31317; it is a whorl fragment showing growth lines.

Type horizon and locality. - Linguipolygnathus inversus conodont Zone, early Emsian; Khodzha Kurgan Gorge, Kitab State Geological Reserve (Uzbekistan).

Material. - Eight slabs (PIMUZ 31318 to 31323) with a total of 18 whorl fragments between 6 and $59 \mathrm{~mm}$ are available. KDB also examined the material published by Becker et al. (2010).

Etymology. - Honoring the great support of Firuza Salimova (Tashkent) and her ongoing research on Palaeozoic stratigraphy in Uzbekistan.

Diagnosis. - Cross section probably laterally flattened and with ventrolateral edges accompanied by two furrows and a ventral band. Ribs weak or absent.

Description. - Both the embryonic shell and the terminal aperture are unknown. Nevertheless, based on comparisons with probably closely related forms and the distinct decrease in curvature of specimens with a whorl height of 1 to $2 \mathrm{~mm}$ (PIMUZ 31318, 31319, 31323) to such with a whorl height of $10 \mathrm{~mm}$ (PIMUZ 31318, 31320; whorl height measured in the flattened state), it appears plausible to conclude that the mature conchs did not grow larger than $100 \mathrm{~mm}$ in diameter. Based on our material, it is not entirely possible to judge whether the shell completed one whorl or not. Because of the flattened preservation, it is not yet possible to reconstruct the whorl cross section. The presence of a strong ventrolateral projection of the growth lines in combination with two well-developed ventrolateral furrows and a ventrolateral ridge (PIMUZ 31317; Fig. 9B) suggest that the shell was, at least in middle and late growth stages, suboval and more or less laterally compressed, possibly with a more or less tabular venter. The characteristic ventrolateral ridges and furrows appear probably stronger than in three-dimensional preservation, because 
Gyroceratites from the same strata displays a similarly preserved ventrolateral structure.

Only in some spots, small parts of growth lines or lirae can be seen, allowing the conclusion that a deep lateral sinus, a high and narrow ventrolateral projection and a deep ventral sinus were present. Most of the larger fragments (e.g. PIMUZ 31320, Fig. 9G) show a fine dorsal crenulation. This crenulation displays about 2 folds per millimetre in the larger specimens (wh $c a .10 \mathrm{~mm}$ ), which fade out from the dorsum to the flanks. It is very irregular and differs in orientation between specimens. Thus, we interpret this feature as being of partially taphonomic origin (compaction), although it likely originated from growth lines or lirae. The holotype PIMUZ 31317 (Fig. 9B), however, shows the ventrolateral salient well and also that the dorsal crenulation leads into structures turning adapically, i.e. into a lateral sinus (wh $c a .9 \mathrm{~mm}$ ). In some places, a very weak ribbing is detectable (Fig. 9B, G).

Only very faint traces of the sutures are visible in specimen PIMUZ 31319 (Fig. 9A top right). These traces reveal an asymmetric lateral lobe that has its steeper side dorsally. The presence of a ventral lobe is likely, but the lobe is not visible.

Remarks. - The overall shell geometry of the new genus is intermediate between Cyrtobactrites and Metabactrites. The very faint ornament is quite untypical for the earliest ammonoids and so is the growth line course and thus the aperture shape of Kitabobactrites. In fact, the growth line course is close to that of members of the genus Gyroceratites.

This raises the question whether Gyroceratites developed from forms like Kitabobactrites, thus implying that coiling evolved twice independently at the transition from bactritids to ammonoids. This would not be so surprising because coiling evolved independently many times in the course of cephalopod phylogeny (e.g. Kröger 2005, Kröger et al. 2011). This phylogenetic hypothesis is supported by the presence of "Ritzstreifen" and similar wrinkle layer (see review and references in Korn et al. 2014) in, e.g. Devonobactrites and Gyroceratites, the growth line course with the strong ventrolateral salient, the presence of a ventral band (Korn 2014 and references therein), and the broad range of umbilical window sizes in Gyroceratites (e.g. De Baets et al. 2012, 2013b). Nevertheless, the alternative hypothesis that Gyroceratites is the sistergroup of Lenzites and forms a monophylum with Chebbites and Gracilites is corroborated by, e.g. the rather smooth morphologic transitions with respect to shell shape and the evolution of the particular growth line course (e.g. Korn 2001, Klug et al. 2015, but see Aboussalam et al. 2015).

Occurrence. - Only from the early Emsian of the Kitab State Geological Reserve (Uzbekistan).

Subclass Ammonoidea Zittel, 1884

Order Agoniatitida Ruzhencev, 1957

Suborder Agoniatitina Ruzhencev, 1957

Superfamily Mimosphinctoidea Erben, 1953

Family Mimosphinctidae Erben, 1953

Subfamily Anetoceratinae Ruzhencev, 1957

\section{Genus Ivoites De Baets, Klug \& Korn, 2009}

Type species. - Anetoceras hunsrueckianum Erben, 1960.

\section{Ivoites meshchankinae sp. nov.} Figure $11 \mathrm{E}-\mathrm{G}$

1976 Anetoceras (A.) cf. hunsrueckianum Erben. - Chlupáč, pp. 304, 305, text-fig. 3 b.

1983 Anetoceras (Teneroceras) cf. hunsrueckianum Erben. -Chlupáč \& Turek, pp. 19, 20, pl. I, fig. 11, pl. 3, figs 3-7.

2010 Ivoites cf. hunsrueckianus Erben. - Becker et al., text-figs $2,5$.

Holotype. - The holotype is a well-ornamented demiwhorl (PIMUZ 31348; Fig. 11G). We designate the specimen figured by Becker et al. (2010, fig. 2.5; B6C.52-1.1), a three-dimensionally preserved whorl fragment from Shirdag (PIMUZ 31347; Fig. 11F) and specimens associated on the slab with the holotype (Fig. 11E) as paratypes, as they show the changes in coiling and ornamentation throughout ontogeny well.

Type horizon and locality. - Linguipolygnathus inversus conodont Zone, early Emsian, Khodza-Kurgan Gorge, Kitab State Geological Reserve (Uzbekistan).

Figure 7. Ammonoids (Mimosphinctinae Erben, 1953; Teicherticeratinae Bogoslovsky, 1969; Parentitinae Bogoslovsky, 1980; and Auguritinae Bogoslovsky, 1961) from the early Emsian Dzhaus Beds. • A - Teicherticeras cf. planum Bogoslovsky, 1980, PIMUZ 31367, note the faint sculpture, the missing whorl overlap and the spiral lines, Shirdag, Kim's section, KS 121. B - Kimoceras lentiforme Bogoslovsky, 1980, PIMUZ 31368 , juvenile specimen, Shirdag, SHK 3A. • C - Convoluticeras flexuosum Bogoslovsky, 1984, PIMUZ 31369, slightly silicified specimen, Shirdag, SHK 50. • D - Gaurites sperandus Bogoslovsky, 1984, PIMUZ 31370, two juvenile specimens, Yusupkul Stow, YUS02CK. • E - body chamber of Kimoceras lentiforme Bogoslovsky, 1980 with subterminal shell fragment of Metabactrites rakhmonovi sp. nov. (paratype), PIMUZ 28869, and pygidium of Exastipyx sp. (not visible here, see Fig. 10), Shirdag, SHK 3A (specimen refigured from Monnet et al. 2011b). F-H - Gaurites sperandus Bogoslovsky, 1984; F - PIMUZ 31371, body chamber of nearly adult specimen, Yusupkul Stow, YUS02CK; G - PIMUZ 31372, premature specimen, Khodzha Kurgan Gorge, KKG 67; H - PIMUZ 31373, premature specimen showing the protoconch, Yusupkul Stou, YUS02CK. 

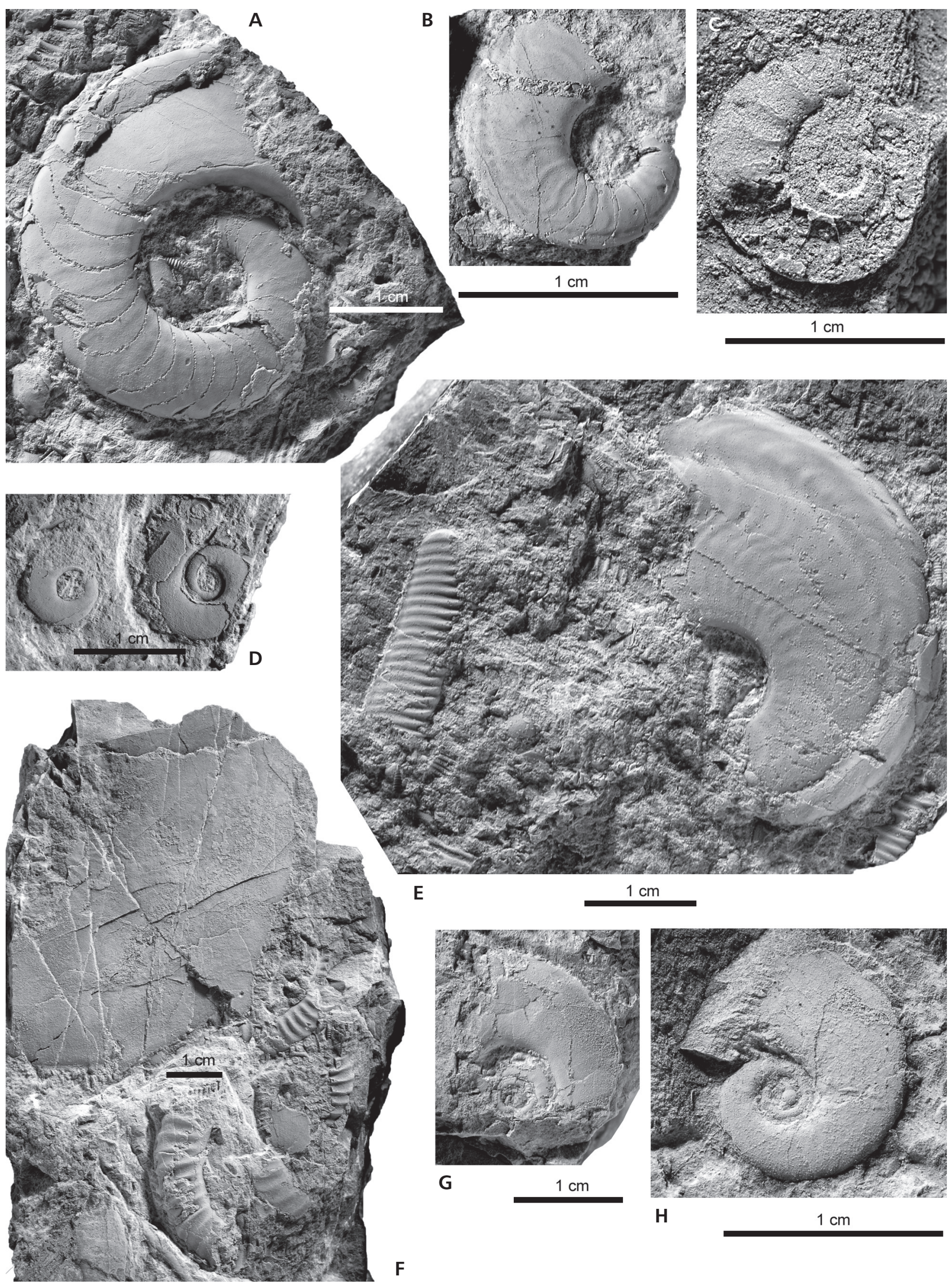
Material. - In total, 5 whorl fragments from Uzbekistan: Holotype PIMUZ 31348, two associated paratypes as well as paratype PIMUZ 31347 and paratype B6C.52-1.1 were collected at Khodzha Kurgan Gorge.

Etymology. - In honour of Natalya Meshchankina (Tashkent), who supported us in the field and for her ongoing research on Palaeozoic stratigraphy in Uzbekistan.

Diagnosis. - Small-sized Ivoites (up to $40 \mathrm{~mm}$ ) with dense ribbing (up to 60 ribs per demi-whorl; ARI10: 33 at wh of $2.1 \mathrm{~mm}$ to 17 at $4.1 \mathrm{~mm}$ ) and uncoiling into the cyrtoconic phase at at diameter around $15 \mathrm{~mm}$; gently curved initial whorl segment and nearly straight terminal shaft; shallow ribs on the juvenile conch and strong, narrowly spaced ribs on the terminal shaft.

Description. - The holotype PIMUZ 31348 has a maximum diameter of about $15.5 \mathrm{~mm}$ and a maximum height of $3.6 \mathrm{~mm}$, which becomes less curved towards the aperture. The ribs are rursiradiate and form a gentle dorsal projection and a shallow ventral sinus. There are 58 fine ribs per demi-whorl with ARI10: 30 at the apical end $(w h=3.6 \mathrm{~mm})$ to ARI10: 17 at the apertural end.

Paratypes associated with the holotype are more curved, have a smaller maximum whorl height (wh: 3.3 and $3.4 \mathrm{~mm}$ ) and a more dense ribbing (ARI10: 29-26) suggesting they represent fragments of specimens, which are yet to uncoil into a straighter shaft.

Paratype PIMUZ 31347 is a $15 \mathrm{~mm}$ long three-dimensionally preserved fragment with a maximum height of $4.1 \mathrm{~mm}$, which is less curved than the holotype. It shows a distinct change in curving towards the end, thus suggesting it forms part of the terminal shaft. The whorl cross section is, as far as it is exposed, suboval. The ribs are more densily spaced at the apical end (ARI10: 21 at wh: $3.1 \mathrm{~mm}$ ) than at the apertural end (ARI10: 17 at wh: $4.1 \mathrm{~mm}$ ).

Paratype B6C.52-1.1 comprises a quarter whorl that measures $20 \mathrm{~mm}$ across and covers an increase in whorl height from 3.3. to $5.6 \mathrm{~mm}$. Accordingly, this only represents the transition to terminal uncoiling/ shaft stage. The rib course is rursiradiate with gently curved lateral portions. The rib spacing decreases from ARI10: 25 to ARI10: 18. Overall, this specimen strongly resembles paratypes associated with the holotype PIMUZ 31348, but it is slightly more strongly curved (i.e. it shows the beginning of the shaft).

Fragments L 17716 and L 17717 from Bohemia (Chlupáč \& Turek 1983, pl. 3, figs 3, 6) have low maximum whorl height (2.3 and $2.4 \mathrm{~mm}$ ), are more curved and have a high rib spacing (ARI10: 30 and ARI10: 25) suggesting they represent earlier ontogenetic stages.

Early demi-whorl (negative counterpart; ICh6837; Chlupáč \& Turek 1983, pl. 3, fig. 4) with a maximum wh of about $2.1 \mathrm{~mm}$ and maximum diameter of about $12.5 \mathrm{~mm}$ is finely ribbed throughout. They initial part with whorl height of about $0.5 \mathrm{~mm}$ is still ribbed, but probably starts close to the end of the embryonic shell. The specimen is densily ribbed with about 60 ribs per demi-whorl at $12.5 \mathrm{~mm}$ to 59 ribs per demi-whorl or ARI10: 33 ribs at a dm of $10 \mathrm{~mm}$.

Specimen ICh5167 from Bohemia (Chlupáč \& Turek 1983, pl. 3, fig. 5) shows the transition from the more coiled part starting with a wh $=2.1 \mathrm{~mm}$ to the shaft ending at a $w h=4.2$. It has already 60 ribs at its maximum diameter (which completes less than a half-whorl) and a corresponding ARI10 of 18 (or ARI5 of 9).

Specimen ICh5405 (Chlupáč \& Turek 1983, pl. 3, fig. 7) measures about $10 \mathrm{~mm}$ across and probably represent a fragment before the uncoiling into the shaft (max. wh: $2.5 \mathrm{~mm}$ ). It has an ARI10 of 29 ribs which is consistent with this interpretation.

Remarks. - None of the specimens displays the earliest ontogeny (initial chamber missing) or the suture lines. Based on the overall conch morphology and ornamentation, the material can be assigned to Ivoites and it appears plausible to assume that its early ontogeny and suture resembles that of other species.

Our specimens are more tightly coiled and more densily ribbed (about 60 ribs per half whorl at 10 to $15 \mathrm{~mm}$ $\mathrm{dm}$ ) than the type species I. hunsrueckianus and most other species of Ivoites [I. medvezhensis Yatskov, 1990, I. opitzi De Baets et al., 2013, I. schindewolfi De Baets et al., 2013, I. tenuis (Barrande, 1865)] as revised by De Baets et al. (2013b). They are also more densily ribbed than M. rakhmonovi. I. meshchankinae is most similar in coiling to specimens of I. tangdingensis (Ruan, 1981) from China, but our specimens are more densily ribbed and the Chinese specimens do not show such a pronounced terminal shaft although the latter could be a collection artefact.

Figure 8. Ammonoids (Mimoceratidae Steinmann, 1890 and Mimagoniatitidae Miller, 1938) from the early Emsian Dzhaus Beds. $•$ A-E - Gyroceratites laevis Eichenberg, 1931, mostly flattened specimens, associated with bivalves and bactritids, Khodzha Kurgan Gorge; A-PIMUZ 31357, large specimen with strong lirae, distinct ventrolateral furrow and external band. The wholes on the flanks might be of diagenetic origin or Housean pits. Note the mature crowding of lirae at the terminal aperture; KKG 43; B - PIMUZ 31358, shows traces of the septa; KKG 40; C - PIMUZ 31359, well-preserved aperture; D - PIMUZ 31360, big, medium and small specimen associated with Kitabobactrites salimovae sp. nov.; KKG 49 m; E - PIMUZ 31361, 3D-preserved juvenile specimen; KKG 23F. $\bullet \mathrm{F}-\mathrm{K}$ - Mimagoniatites fecundus (Barrande, 1865); F - PIMUZ 31362, two fragments showing lirae (left) and the tabular venter with angular edges (right); G - PIMUZ 31363, preadult whorl showing lirae; H - PIMUZ 31364, fragmentary body chamber showing the moderately wide umbilicus; I - PIMUZ 31365, part of the neanoconch; J, K - PIMUZ 31366, adult body chamber with strong lirae. 

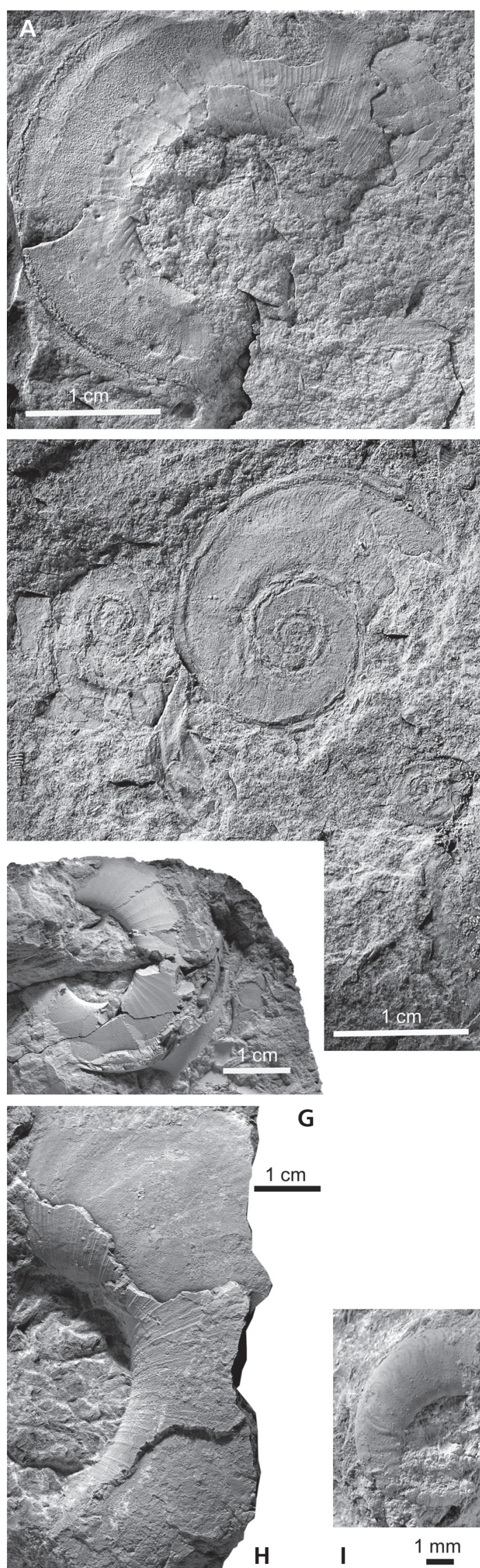
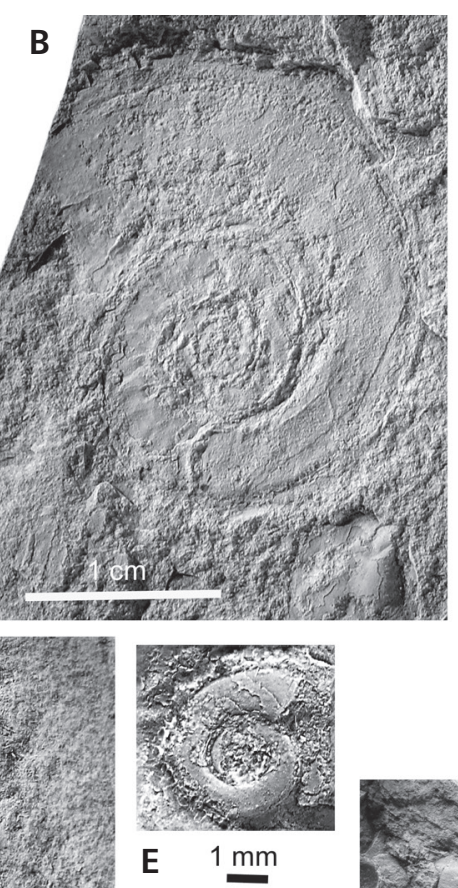

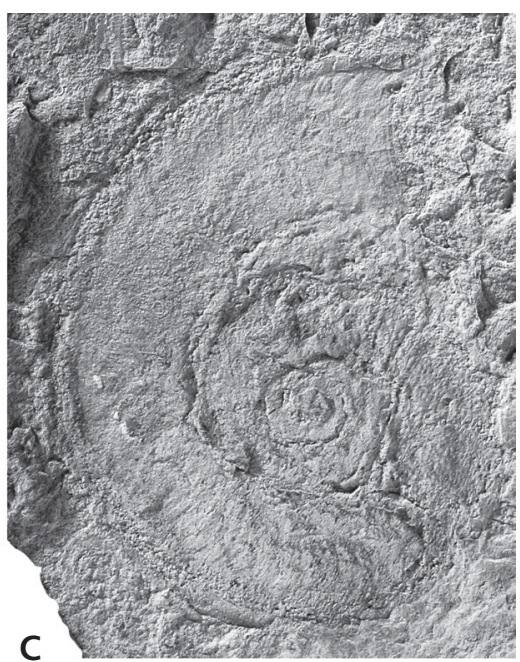

$1 \mathrm{~cm}$
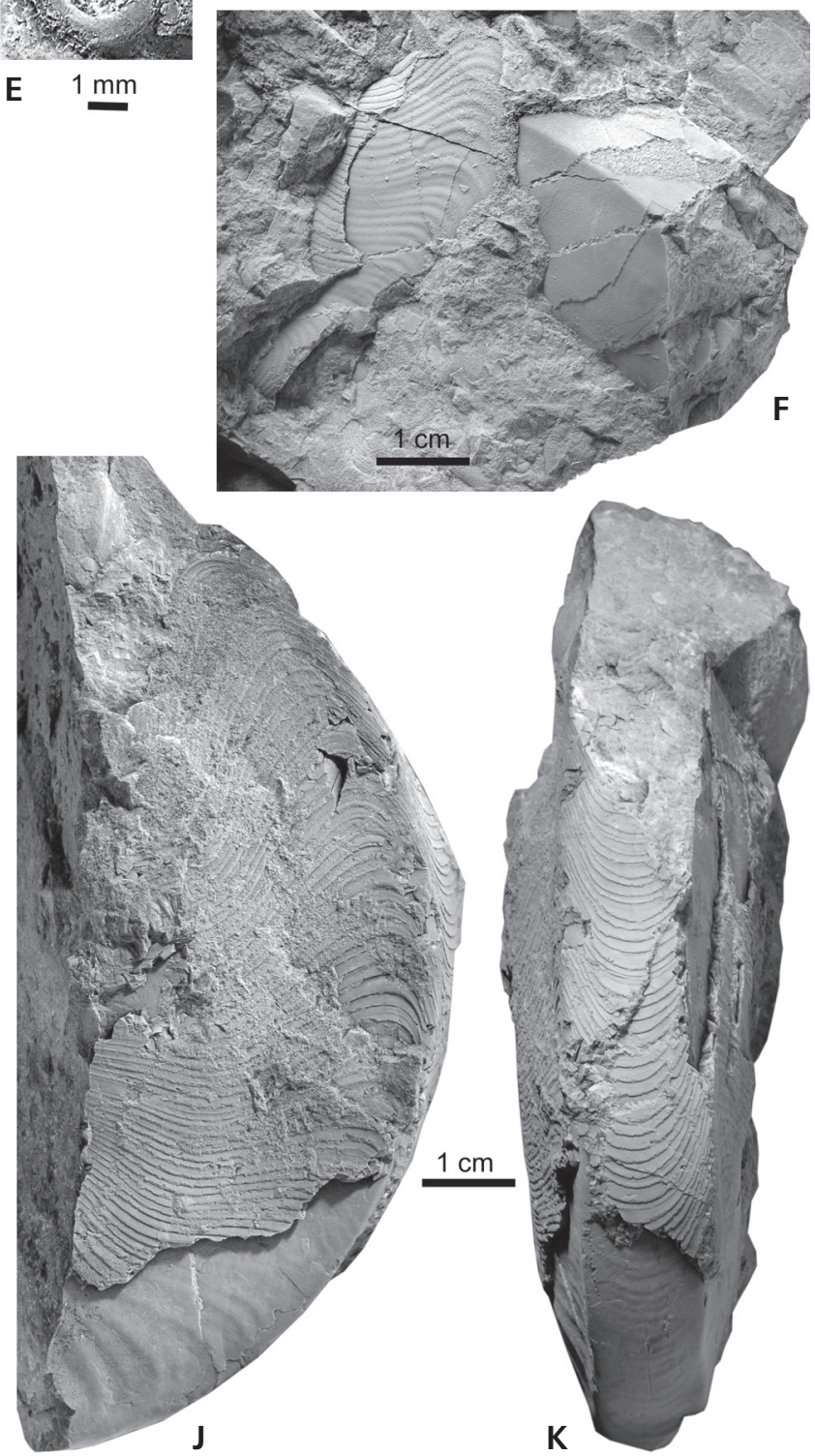


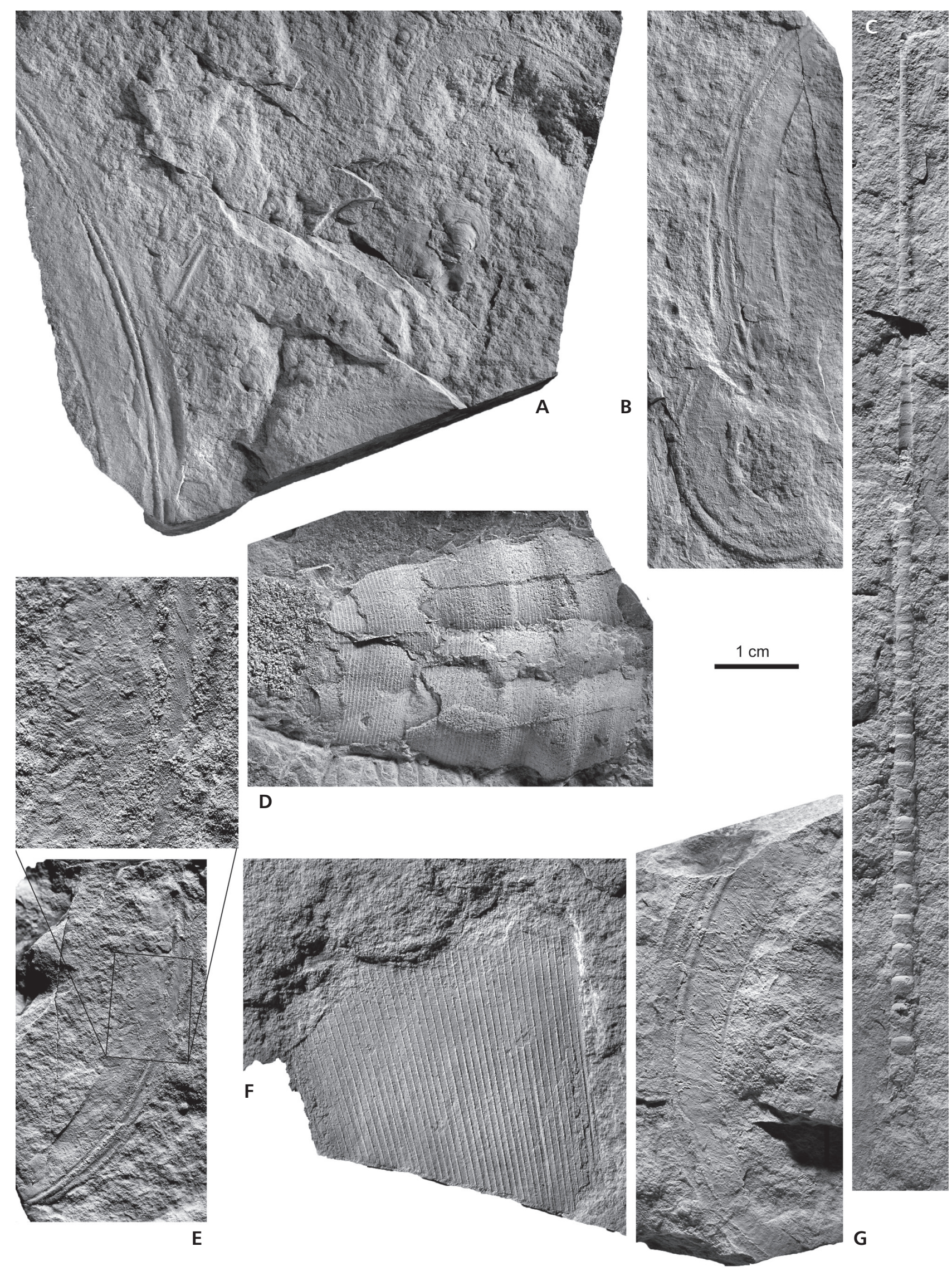



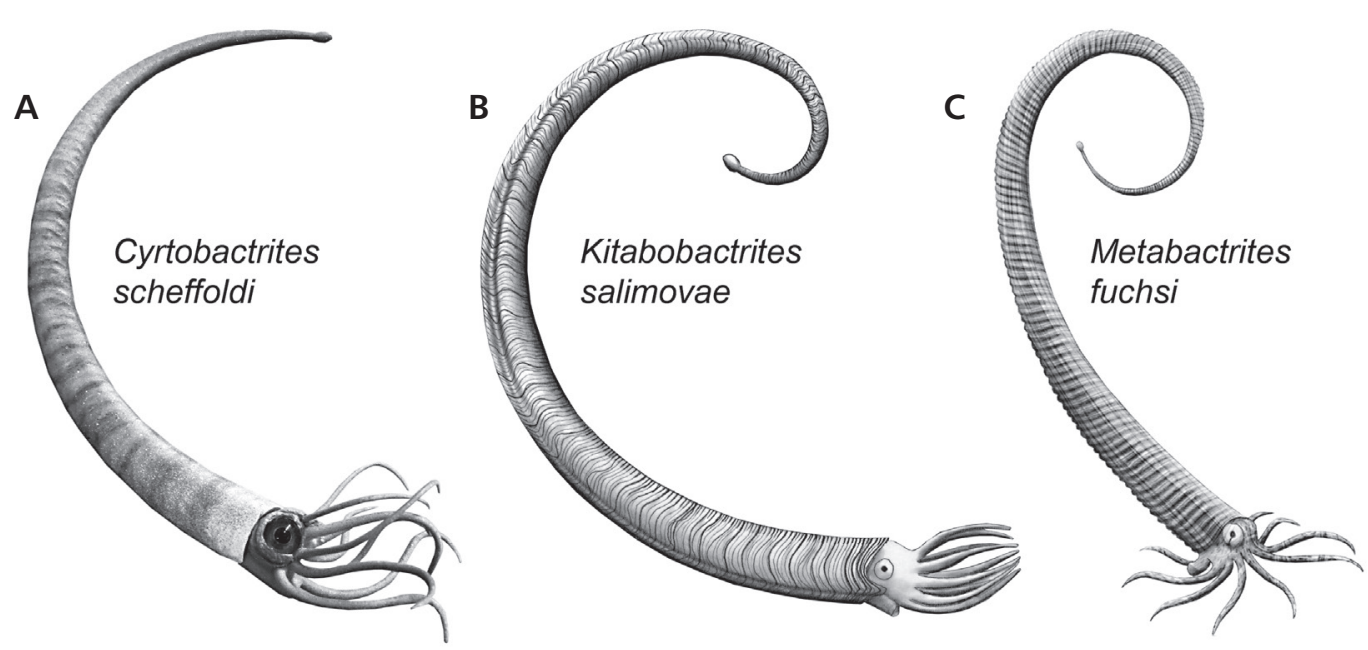

Figure 10. Reconstructions of some coiled bactritids (A, B) and an early ammonoid (C) from the early Emsian. - A - plastic model made by Beat Scheffold (Zürich) of Cyrtobactrites scheffoldi Klug et al., 2008; Tafilalt, Morocco. • B - reconstruction of Kitabobactrites salimovae sp. nov.; Khodzha Kurgan Gorge, Uzbekistan; based on various whorl fragments including the holotype. The shell completes one whorl, but the aperture and ornamentation resembles other bactritids. • C - Reconstruction of Metabactrites fuchsi De Baets et al., 2013b, modified after De Baets et al. (2013b); Hunsrück, Germany.

Occurrence. - The species is known from the early Emsian of the Kitab State Geological Reserve (Uzbekistan) as well as from Bohemia (previously described as $I$. cf. hunsrueckianus). They are most common in the Nowakia elegans Zone, but the species can range from the Now. barrandei to the lower part of Now. cancellata dacryoconarid Zone in Uzbekistan. In Bohemia, they have so far only been confidently reported from the Now. elegans Zone - although a specimen from the Zlíchov Limestone could potentially be older (Chlupáč \& Turek 1983).

\section{Genus Metabactrites Bogoslovsky, 1972}

Type species. - Metabactrites formosus Bogoslovsky, 1972 by original designation.

\section{Metabactrites rakhmonovi sp. nov.}

Figure 11I

2010 ?Metabactites n. sp. - Becker et al. 2010, pp. 21, 22, fig. 2.6.

2011 loosely coiled anetoceratid. - Monnet et al. 2011b, fig. 3 e.

Types. - The holotype is specimen PIMUZ 31350 (Fig. $11 \mathrm{~J})$. We designate the specimens figured by Becker et al.
(2010, fig. 2.6; B6C.52-1.2) and well-ornamented whorl fragment (PIMUZ 28869) already published earlier by Monnet et al. (2011b, fig. 3e) as paratypes.

Type horizon and locality. - Linguipolygnathus inversus conodont Zone, early Emsian, Shirdag, Kitab State Geological Reserve (Uzbekistan).

Material. - In total 3 whorl fragments: Holotype PIMUZ 31350 and paratype PIMUZ 28869 were collected at Shirdag, paratype B6C.52-1.2 is from Khodzha Kurgan Gorge.

Etymology. - To remember Utkir J. Rakhmonov (Shahrisabz), who recently passed away and who put so much effort into keeping the Kitab State Geological Reserve and the regional research there running, and also to show our great appreciation of his warm-hearted hospitality and great help during our visits.

Diagnosis. - Metabactrites with gently curved initial whorl segment and nearly straight terminal shaft, shallow, narrowly space ribs setting in on the juvenile conch (ARI5: 9-7) and strong, less narrowly spaced ribs on the terminal shaft (ARI5: 6).

Figure 9. Cephalopods from the early Emsian Dzhaus Beds. • A, B, E, G - Kitabobactrites salimovae sp. nov., all Khodzha Kurgan Gorge, KKG 88; A - PIMUZ 31318, incomplete remains of various growth stages of six K. salimovae gen. et sp. nov, note the more strongly curved early part (top right and left above the center) and the cyrtoconic later part (left and bottom) of the shell, associated bivalves (probably ligament preserved at burial); B - PIMUZ 31317, holotype, (top) associated with Gyroceratites cf. laevis Eichenberg, 1931; E - PIMUZ 31317, holotype, Khodzha Kurgan Gorge, KKG 88; G - PIMUZ 31320. C - Orthocerida indet., PIMUZ 31345, Khodzha Kurgan Gorge, KKG 33m. • D - Orthocycloceras sp., PIMUZ 31344 , Yusupkul Stou, YUS2CK. • F - Kionoceratidae indet., PIMUZ 31320, Khodzha Kurgan Gorge, KKG 88. 


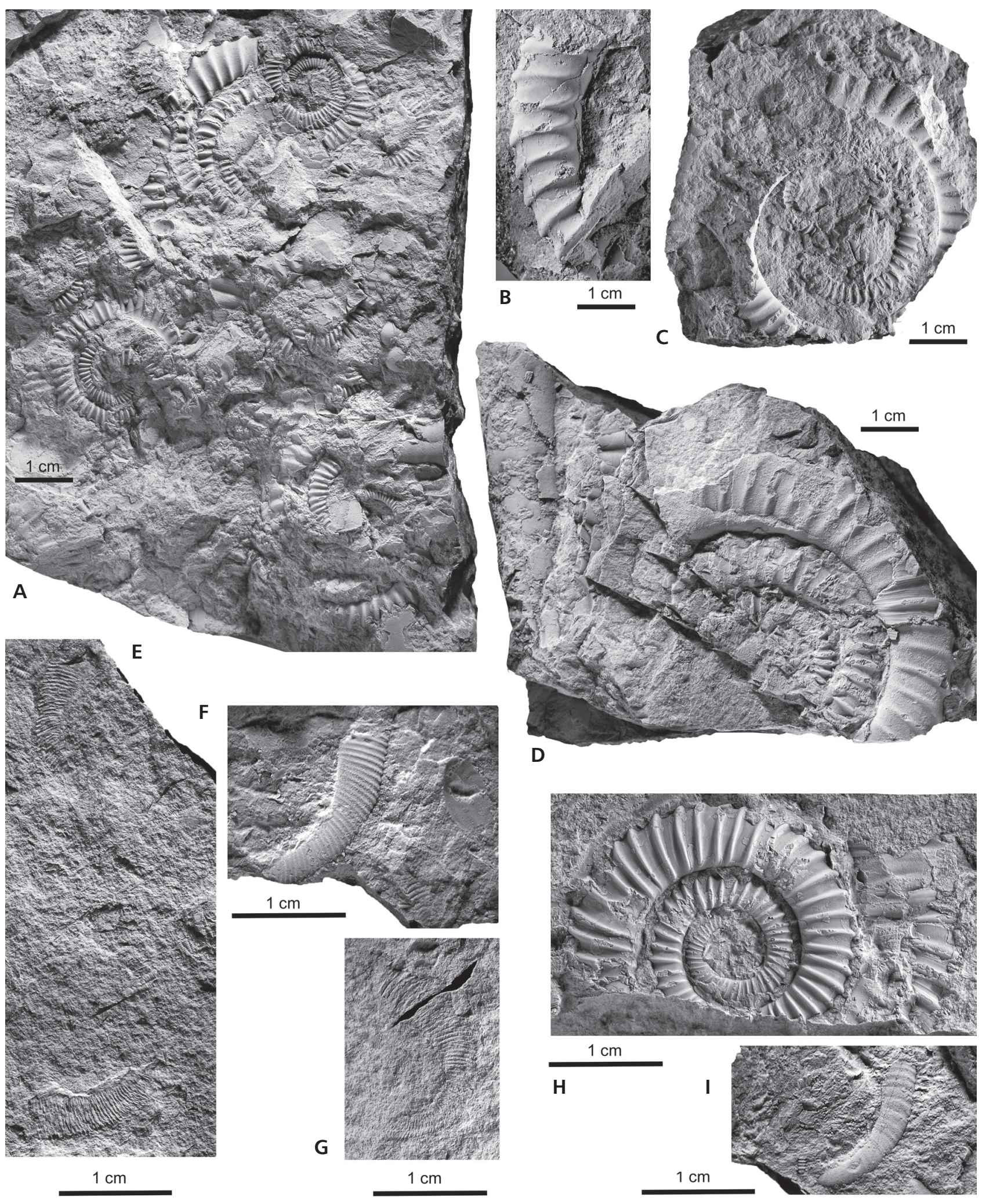

Figure 11. Ammonoids (Anetoceratinae Ruzhencev, 1957) from the early Emsian Dzhaus Beds. • A, D, H - Erbenoceras kimi Bogoslovsky, 1980, associated with orthocerid remains and gastropods, PIMUZ 31324, Yusupkul Stou, YUS02CK; D - PIMUZ 31346, Yusupkul Stou, YUS01KDB; H - PIMUZ 31349, Yusupkul Stou, YUS01KDB. • B, C - Erbenoceras advolvens (Erben, 1960), PIMUZ 31375, Shirdag, Kim's section, KS92. • E-G - Ivoites meshchankinae (Erben, 1960); E, G - PIMUZ 31348, Khodzha Kurgan Gorge, KKG 107; F - PIMUZ 31347, Shirdag, SHK3A. • I - Metabactrites rakhmonovi sp. nov., PIMUZ 31350, holotype, Shirdag, SHK3A. 

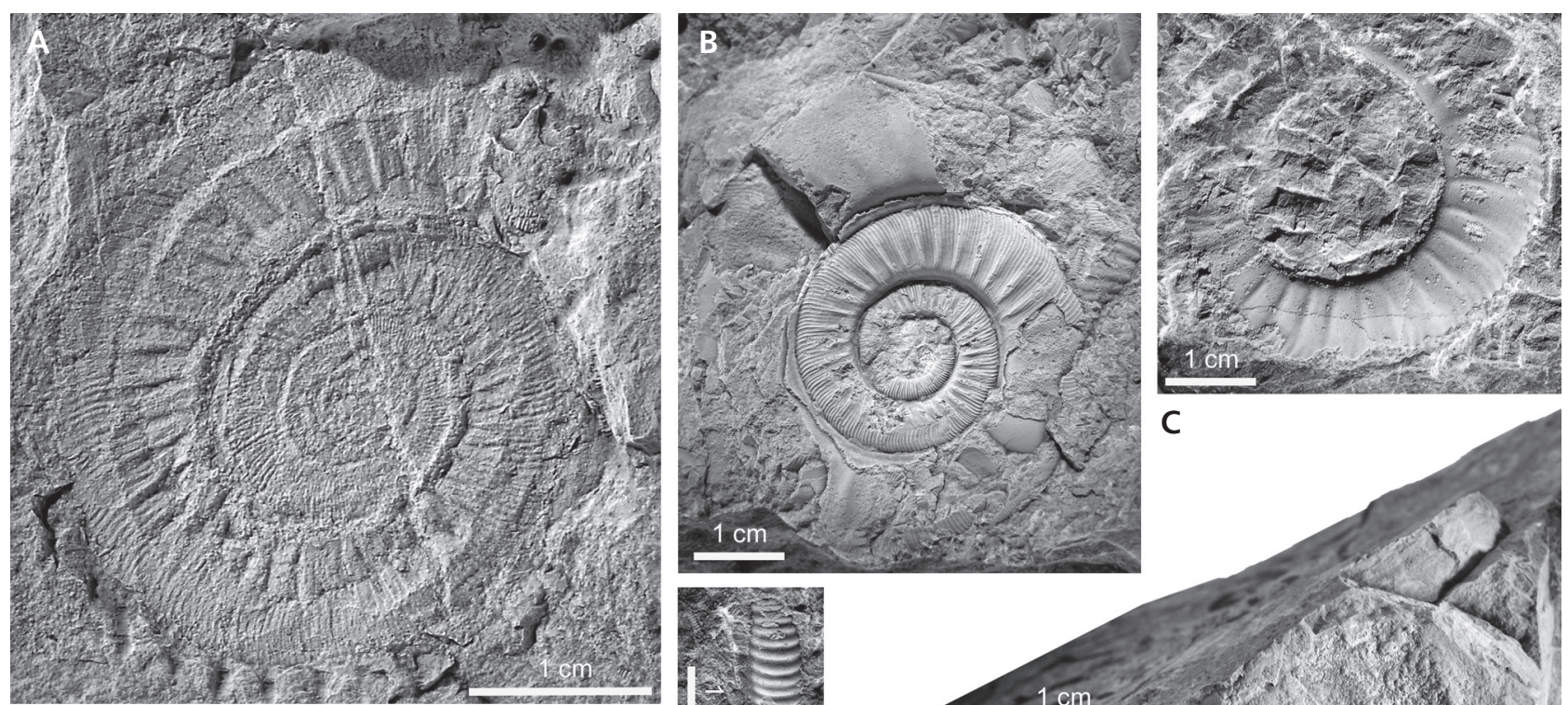

C
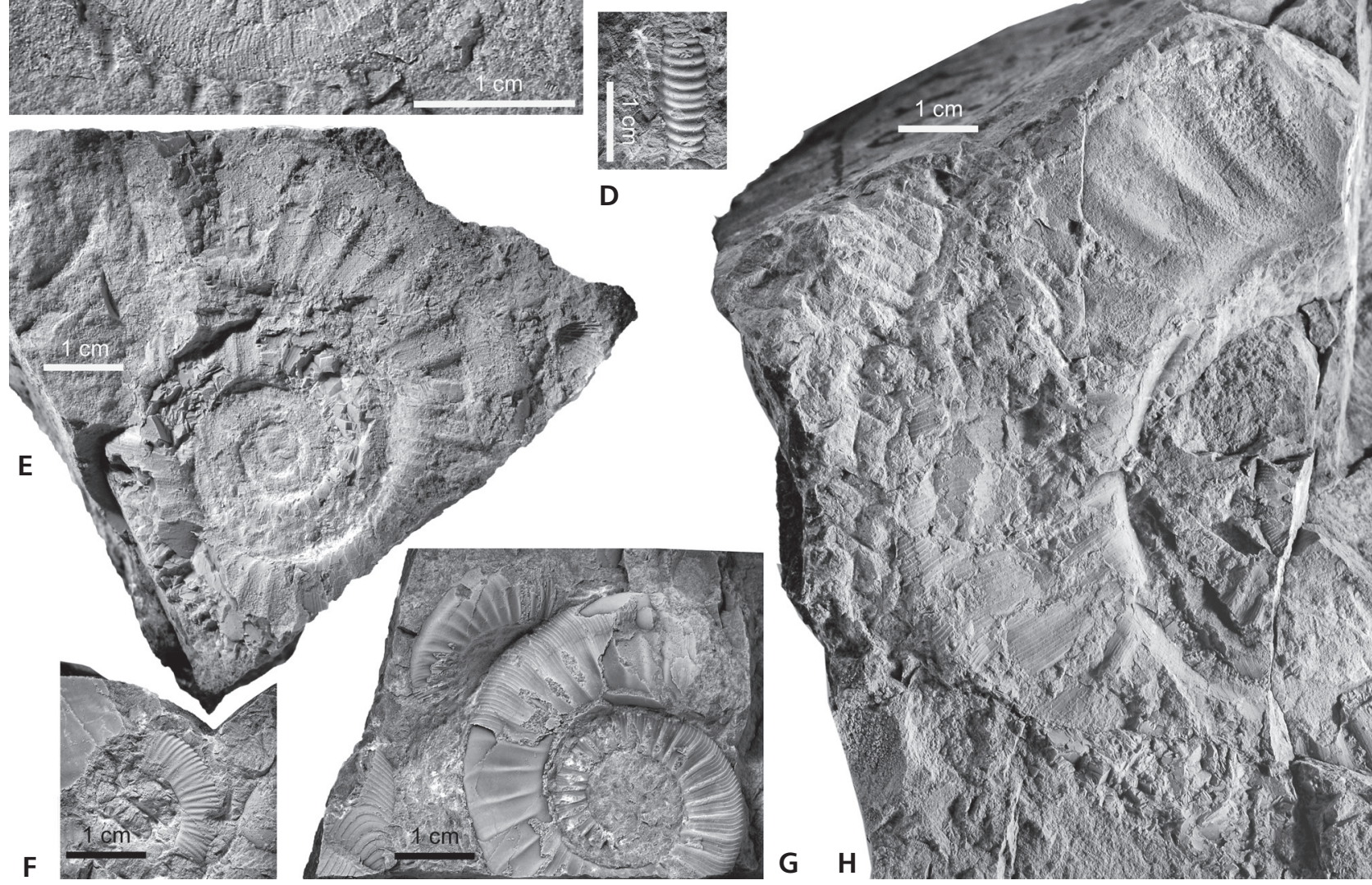

Figure 12. Ammonoids (Mimosphinctinae Erben, 1953) from the early Emsian Dzhaus Beds. • A, B, E, G, H-Uzbekisphinctes rudicostatus Bogoslovsky, 1980 comb. nov.; A - PIMUZ 31351, flattened specimen, associated with large orthocerids, Khodzha Kurgan Gorge, KKG 105; B - PIMUZ 28595, specimen with sublethal injury, Khodzha Kurgan Gorge, bed 48, Linguipolygnathus inversus Zone, KKG 48 m (reproduced from De Baets et al. 2011); E - PIMUZ 31354, slightly deformed specimen, Khodzha Kurgan Gorge, bed 49 m, Ling. inversus Zone; G - PIMUZ 31356, Khodzha Kurgan Gorge, bed $38 \mathrm{~m}$, Ling. inversus Zone; H - PIMUZ 31357, very large deformed specimen, Khodzha Kurgan Gorge, Ling. inversus Zone, KKG 103. • C, D, F - Beckeroceras khanakasuense (Yatskov, 1990); C - PIMUZ 31352, Shirdag, SHK3A; D - PIMUZ 31353, fragment showing ventral ribbing, Shirdag, SHK3A; F - PIMUZ 31355, Shirdag, SHK3A.

Description. - The holotype PIMUZ 31350 (Fig. 11J) is a $12 \mathrm{~mm}$ long and $2.5 \mathrm{~mm}$ wide fragment, which is much more distinctly curved than the paratype PIMUZ 28869 (Fig. 7E). The cross section can also be reconstructed as being suboval. The ribs are nearly invisible near the apical end of the fragment (wh $c a .1 .6 \mathrm{~mm}$ ) and become increas- ingly sharp towards the apertural end of the fragment (ARI5: 7; ARI10: 15).

The paratype PIMUZ 28869 is a $17 \mathrm{~mm}$ long and $5.5 \mathrm{~mm}$ wide fragment, which is hardly curved (ARI5: 6; ARI10: 10-12). The whorl cross section is, as far as it is exposed, suboval. The ribs are rursiradiate and form a gentle dorsal 
projection and a shallow ventral sinus. There are 19 strong ribs distributed over a length of $17 \mathrm{~mm}$.

Paratype B6C.52-1.2 is half a whorl that measures $10 \mathrm{~mm}$ across and covers an increase in whorl height from 1 to $2.5 \mathrm{~mm}$. Accordingly, there is only a very short whorl fragment and the protoconch missing apically. As in the other paratype, the adapical conch part does not reveal ribs (ARI5: 9; ARI10: 21); these develop more or less in the middle of the fragment at a whorl height of $c a$. $1.8 \mathrm{~mm}$. The rib course is rursiradiate with shallow dorsal and ventral sinuses and gently curved lateral portions. Overall, this specimen strongly resembles paratype PIMUZ 31350, but it is more strongly curved and represents the smallest known (probably the youngest) individual.

None of the specimens displays the suture lines. Based on the overall conch morphology and ornamentation, the material can be assigned to Metabactrites and it appears plausible to assume that its suture resembles that of the type species.

Remarks. - Conch geometry, rib course, rib spacing, and ontogenetic changes allow the assignment to the genus Metabactrites. The type species Metabactrites formosus Bogoslovsky, 1972 has less densily spaced ribs while M. fuchsi De Baets et al., 2013b has more densely spaced ribs as measured by the rib index. M. fuchsi appears to have a slight lateral sinus in the ribs, absent in the new species (De Baets et al. 2013b). Also, ribbing begins already at a whorl height below $1 \mathrm{~mm}$, where the conch of M. rakhmonovi sp. nov. is still smooth. M. formosus does not seem to show a tendency to form a shaft as straight as in the new species.

Occurrence. - Only from the early Emsian of the Kitab State Geological Reserve (Uzbekistan).

Subfamily Mimosphinctinae Erben, 1953

\section{Genus Beckeroceras gen. nov.}

Type species. - Erbenoceras khanakasuensis Yatskov, 1990.

Diagnosis. - A mimosphinctin without an imprint zone, a low whorl expansion rate (1.6 to 2.1 ) and a dorsal saddle.

Etymology. - In honor of Ralph Thomas Becker (Münster) and his enormous contribution to research on Devonian stratigraphy worldwide. Also, he suggested to introduce this genus already earlier (Becker et al. 2010) and kindly allowed us to complete this mission.

Species included. - Only the type species.
Remarks. -The genus Mimosphinctes used to be characterized by advolute to very evolute shells with bi- or trifurcating rursiradiate ribs. Depending on the absence or presence of an imprint zone, a dorsal lobe developed or not. In the new genus (Fig. 12C, D, F), we include all forms with coarse bi- or trifurcating rursiradiate ribs lacking an imprint zone and a dorsal lobe (compare Becker et al. 2010, p. 20). In contrast to Beckeroceras, Chebbites has no intercalatory ribs, Mimosphinctes is more tightly coiled and has a dorsal lobe, Uzbekisphinctes gen. nov. is more tightly coiled and has more narrowly spaced intercalatory ribs, while Talenticeras has a loosely coiled terminal whorl with a narrow gap between the whorls.

From a phylogenetic point of view, the now more narrowly defined genus Mimosphinctes represents the more derived state compared to Beckeroceras gen. nov. due to its tighter coiling and the evolution of a dorsal lobe. Korn \& Klug (2002) included the genera Chebbites, Talenticeras, and Mimosphinctes in the Mimosphinctinae; according to Korn (2001, fig. 8), the Mimosphinctinae would thus be paraphyletic because these genera would stemgroup representatives leading to more derived clades such as the mimoceratids, mimagoniatitids and auguritids, if Korn's (2001) phylogenetic hypothesis is correct. When looking at the shell geometry, ornamentation and suture lines, great similarities between Mimosphinctes and Erbenoceras kimi become visible. Notably, Erbenoceras kimi is more or less advolute and sometimes, ribs might bifurcate. In this context, one would expect an evolutionary trend towards tighter coiling, but at least the last whorl of Talenticeras is less tightly coiled than in Erbenoceras kimi or Beckeroceras. With our current knowledge, we cannot resolve this contradiction entirely, but we suggest that Talenticeras might be part of a different lineage.

Occurrence. - Dzhaus Beds (Emsian), Zeravshan Mountains (Uzbekistan).

\section{Genus Uzbekisphinctes gen. nov.}

Type species. - Teicherticeras (Convoluticeras) rudicostatum Bogoslovsky, 1980.

Diagnosis. - Mimosphinctin with an imprint zone, a low whorl expansion rate (1.7 to 2.5 ), a dorsal saddle and a great number of fine secondary ribs.

Etymology. - After Uzbekistan, which hosts the Kitab State Geological Reserve, from where the type species was first described and figured on a stamp.

Remarks. - Typical Mimosphinctes (like the type species M. tripartitus) with an imprint zone have coarse bi- or trifurcating rursiradiate ribs, while the specimens included in 
Uzbekisphinctes have also an imprint zone, but much finer intercalated ribs and higher degree of coiling (Fig. 12A, B, E, G, H). The groups have already been individualized by other authors (Becker et al. 2010, De Baets et al. 2013b, Klug 2017). When looking at shell geometry, ornamentation and suture lines, great similarity exist between $U$. discordans Erben, 1965 and U. rudiscostatus Bogoslovsky, 1980. The holotype of "Mimosphinctes" primigenitus Erben, 1965 also has finely ribbed secondaries and is very similar in the characters, which are present in this genus (De Baets et al. 2013b). Some specimens attributed to M. erbeni Bogoslovsky, 1980 (auct.) from Uzbekistan and M. tenuicostatus Bogoslovsky, 1963 from the Northern Urals also have finer intercalated ribs, but these species are typically more evolute and have a higher primary rib to secondary rib ratio (Klug 2017). From a phylogentic point of view, the new genus Uzbekisphinctes represents a derived form within the Mimosphinctidae due to its tighter coiling, the evolution of a dorsal lobe as well a larger amount of fine secondary ribs. Beckeroceras lacks an imprint zone, has a more loosely coiled conch without an imprint zone and shows differences in ornamentation including coarser primaries and secondaries.

Species included. - Convoluticeras discordans Erben, 1965 (p. 300), Daleje Shale, Bohemia (Czech Republic); Teicherticeras (Convoluticeras) rudicostatum Bogoslovsky, 1980 (p. 58), Dzhaus Beds, Zeravshan Mountains, Uzbekistan; Teicherticeras primigenitum Erben, 1965 (p. 284), Middle Kaub Formation, Hunsrück, Germany.

Occurrence. - U. rudicostatus is so far only known from Uzbekistan. $U$. discordans has been reported from Bohemia in the Czech Republic, the Rhenish Mountains in Germany and Guangxi in South China (Ruan 1981, 1996; Yu \& Ruan 1988). Well-dated specimens derive from the Nowakia elegans to Now. cancellata Zone of China (Yu \& Ruan 1988) and Uzbekistan. U. rudicostatus can also range into the upper part of the Now. barrandei Zone (Becker et al. 2010). The range of the Hunsrück Slate ammonoid fauna containing M. primigenitus into the Now. barrandei and Now. elegans Zone (De Baets et al. 2013b) would also be compatible with known ranges of Uzbekisphinctes in other regions.

\section{Discussion}

The transition from the $1000 \mathrm{~m}$-thick massive platform carbonate of the Madmon Formation (Lochkovian, Pragian; Yolkin et al. 2008) via neritic limestones with brachiopods and reef-debris of the Khukarian (Pragian), Zinzilban and Norbonak Beds (both earliest Emsian in the current GSSP sense; Yolkin et al. 2008) to Emsian pelagic limestones with dacryoconarids and ammonoids (Dzhaus Beds) in a less than $250 \mathrm{~m}$-thick interval suggests a quite rapid change of the palaeoenvironmental settings in this area. We were interested in this transition from a more neritic (late Pragian) to a more pelagic facies (early Emsian), which evolved before the onset of the ammonoid assemblages in this area. In this context, we therefore aimed to improve our understanding of the involved regional geological processes. In the following, we discuss the facies changes that occurred during the Pragian and early Emsian and possible interpretations.

\section{Late Pragian at Bursykhirman Mountain}

The presence of both shallow-water benthic reef-builders and dacryoconarids, a group assumed to have been pelagic (Bouček 1964, Berkyová et al. 2007, Wittmer \& Miller 2011), locates the palaeo-position of the studied deposits in the neritic zone of an open-marine shelf in the fore-reef area (compare Botquelen et al. 2001, Machel \& Hunter 1994). Indeed, the occurrence of these fossil groups with such different living habitats suggests a connection with the open marine environment. The lower part of this section is dominated by massive peloidal limestones containing fossils of reef-builders such as tabulate corals and brachiopods suggesting a moderately high level of energy in a shallow marine environment. This carbonate factory was likely located on an open-shelf, still above the storm-wave base (SWB; compare Machel Hunter 1994 for the Middle to Late Devonian). The changing facies in the interval between 75 and $100 \mathrm{~m}$ above base in the Bursykhirman section documents a change towards deeper water with pelagic conditions as corroborated by the increasing abundance of dacryoconarids. They are not current-aligned and their chaotic orientation suggests still a moderately high level of energy. This would suggest a paleodepth near the SWB. In parallel, the siliciclastic content slightly increased.

In this context, the question arises how the carbonate platform growth came to its end. Classically, such settings where platform carbonates are conformably overlain by pelagic sediments were interpreted as 'platform drowning' (see tab. 1 in Schlager 1981). As convincingly explained by Schlager (1981), it is quite unlikely that subsidence rates exceed the growth rates and sediment accumulation rates of reefs and carbonate platforms. Schlager (1981, p. 208) listed two main causes for platform drowning: (1) "Reduction of benthic growth due to environmental stress" (by salinity drops or rapid drift to higher latitudes) or (2) "rapid pulses of relative sea-level". Alternatively, platform growth might have been inhibited by its emergence due to a regression or tectonic uplift. A subsequent transgression can then bring a sequence of neritic and eventually pelagic 
Table 1. Unitary Associations of the studied sections. Grey rectangles indicate the occurrence of the species in the assemblage.

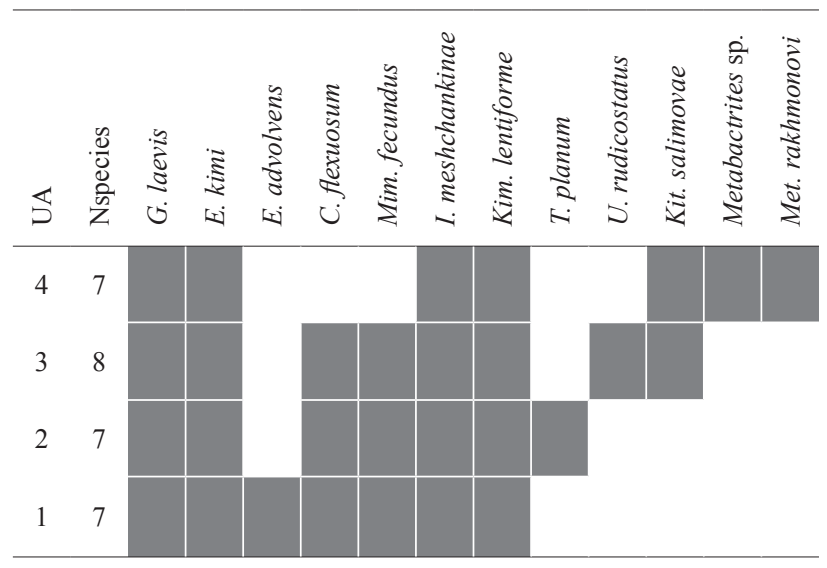

platforms, because the main carbonate producers were regionally erased.

Evidence for environmental stress is lacking, since many carbonate-producing benthic faunal elements existed before and after the main facies change; also, evidence for salinity drops or rapid drift to higher latitudes are missing as well. By contrast, a global sea-level rise occurred, e.g. during the Pragian and earliest Emsian (e.g. Haq \& Schutter 2008). Whether these transgressive pulses were strong and rapid enough to cause a platform drowning cannot be decided based on our information.

Also, we did not find evidence for a temporal emergence of the Madmon Formation-carbonate platform; a more detailed survey of the transition between the Madmon Formation and the Khodzha Kurgan Formation (i.e. between the Khukarian and the Zinzilban Beds) might shed more light on the involved processes. It is thus unclear whether the transgressions that occurred from the time of deposition of the Khukarian Beds to the Zinzilbanian Beds documented in our section caused the cessation of platform growth or not. Reef-building organisms still occur in the interval between 100 and $138 \mathrm{~m}$ above the base of the Bursykhirman section, but for some reason not in a sufficient number to resume platform growth. Remarkably, the transition from neritic to pelagic fine-grained sediments with a thin interval containing phosphatic and iron-oxide elements in between suggest a short phase of non-deposition or at least low sediment accumulation rates, killing off of what remained of the reef fauna.

So how do the regional sea-level changes correlate with global transgressive events (e.g. Johnson et al. 1985, Haq \& Schutter 2008)? Even though the Pragian to early Emsian transgressions may correlate with a global transgressive event, we are not entirely certain whether it correlates with the Basal Zlíchov Event (House 1996) or, as suggested by Carls et al. (2008), the transgression Ia of Johnson et al.
(1985); this partially roots in the need of redefinition of the Pragian-Emsian boundary in Uzbekistan. Nevertheless, we found possible tectonic features both around the boundary between the Madmon and the Khodzha Kurgan Formations (Fig. 13) and towards the end of the section (top of the Khukarian Beds); these structures evoke some uncertainty since parts of the section might be missing.

\section{Ammonoid succession and the Daleje Event \\ Correlation of the sections and bathymetric changes during the Early Devonian}

The Khodzha Kurgan West section corresponds to unit 15 of the detailed section in Yolkin et al. (2008). In this section, Erbenoceras kimi and ?Gyroceratites laevis (or G. heinricherbeni) are the most common species. Yolkin et al. (2008) and Becker et al. (2010) also documented occurrences of Mimosphinctes tripartitus Eichenberg, 1931 and M. erbeni (auct.), which we did not find. Nevertheless, we found Erbenoceras advolvens, Convoluticeras flexuosum and Kimoceras lentiforme in this unit.

Concerning the second Khodzha Kurgan section, it represents stratigraphically more or less the continuation of the previous one; the last two metres of Khodzha Kurgan West correlate roughly with the first two metres of the Khodhza Kurgan Gorge section. This section corresponds to unit 16 of Yolkin et al. (2008). In this section, neither Mimosphinctes tripartitus nor M. erbeni (auct.) have been found during our investigations - but see Becker et al. (2010) for a summary of previous reports.

In Yolkin et al (2008) and Becker et al. (2010), there is a well-defined turnover in ammonoid taxa around bed 47. Indeed, Erbenoceras kimi and Mimosphinctes tripartitus disappear almost synchronously when Mimagonitatites fecundus, Convoluticeras flexuosum and Uzbekisphinctes rudicostatus appear. In the subsequent beds, Uzbekisphinctes rudicostatus co-occurs with Gyroceratites laevis and M. erbeni (auct.). This turnover coincides with the appearance of the dacryoconarid Nowakia cancellata, which marks the global transgressive Daleje Event (sensu House 1985, 1996; Chlupáč \& Kukal 1986). Transposing this information to our studied section, this ammonoid turnover appears less profound. Even though these three genera range into the late Emsian, it is interesting that Uzbekisphinctes rudicostatus occurs far below the Daleje Eventinterval, while Mimagoniatites continues until the top of the section. In this respect, our findings differ slightly from those of Yolkin et al. (2008) and Becker et al. (2010).

Another question is linked with the last occurrence of Ivoites meshchankinae sp. nov. In all other sections, where this taxon occurs, it disappears before the Nowakia 

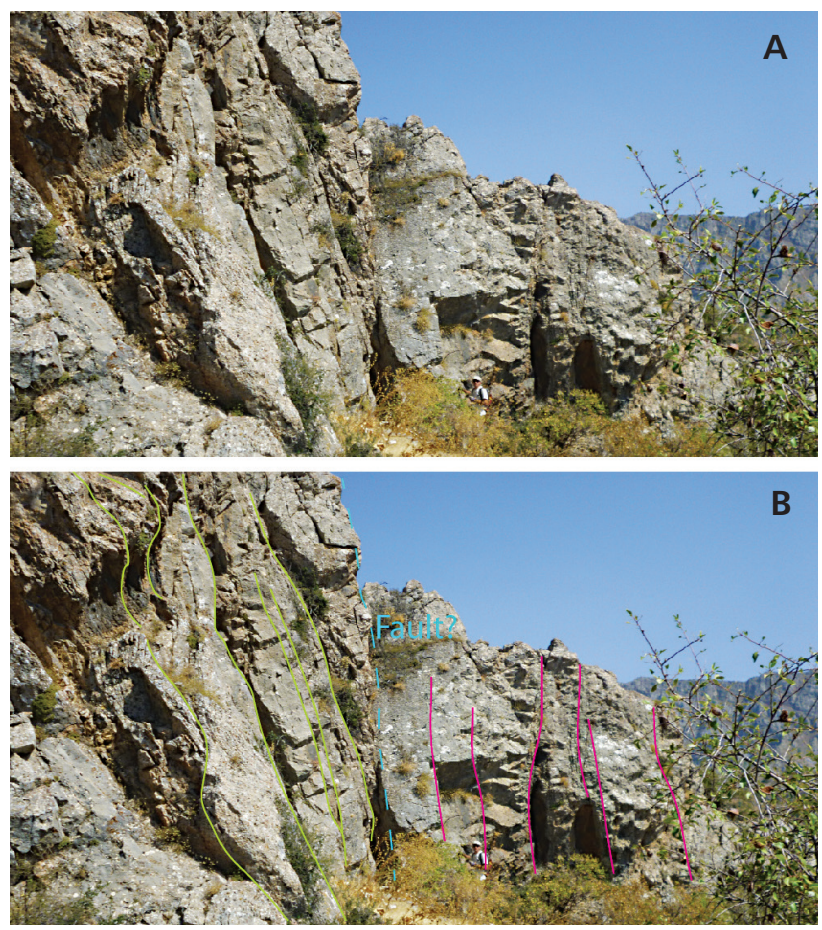

Figure 13. Top of the Bursykhiman section. $\cdot \mathrm{A}-$ the original picture (person at the bottom of the picture for scale). $\bullet \mathrm{B}$ - bed limits marked showing a slight variation of dip, and the possible occurrence of a fault. Older beds are marked in green, younger ones are marked in pink and the possible fault is represented in light blue.

cancellata Zone, i.e. it became extinct before the Daleje Event. In the Khodza-Kurgan Gorge, it is still present in the lower part of the Now. cancellata Zone where also Now. elegans is still present.

As corroborated by the ammonoid occurrences and the increased clay content (covered interval) $60 \mathrm{~m}$ above the base of the Bursykhirman section, the Daleje Event in the Khodzha Kurgan section can be placed approximately here. But it is difficult to clearly define a limit at a specific metre rather than an interval, and this statement has two reasons. First, contrarily to some dramatic rapid transgressions, the Daleje transgressive Event is known to be a long-term gradual event (Carls \& Valenzuela-Ríos 2002). Secondly, this difficulty roots also in the quite distal location from the coast; compared to a more proximal platform setting on a slope, which would have been strongly affected by sea-level changes and thereby controlling the facies, the sediments do not show a profound difference and they do not become darker like in some other localities (Chlupáč $\&$ Kukal 1988). The facies consists of pelagic limestones throughout the section as reflected in the great abundance of dacryoconarids. Ninety metres above the base of the section, beds displaying irregular surfaces suggest that they maybe formed by sediment gravity flows or slumps. Subsequently, the sediments become slightly darker, suggesting possibly lower oxygen levels. Simultaneously, the fossil content decreases as well. The last two metres of the section contain massive limestone layers, which were probably formed in a more proximal setting compared to the beginning of the section.

The distribution of ammonoids in Shirdag is different compared to Khodhza Kurgan. Presuming it is correct that the North section starts at the boundary between the Norbonak and Dzhaus Beds, it is unusual for this region according to our own experience that the ammonoid occurrences start with an early presence of Ivoites meshchankinae sp. nov., appearing simultaneously with Erbenoceras kimi, and even before Gyroceratites laevis. Moreover, both species disappear quite early within the first 20 metres of the section. The first occurrence of Mimagoniatites fecundus coincides more or less with the last occurrence of Ivoites meshchankinae in bed 50. Erbenoceras kimi is still present until 40 metres above base, thus suggesting this layer being still below the Daleje Event. Uzbekisphinctes rudicostatus appears higher up in the section, more or less with Kimoceras lentiforme, which is also peculiar since K. lentiforme appears early in other sections, suggesting this interval is still below the Daleje Event, too. Speaking about this Event, the most likely position to place it would be in the interval between $40 \mathrm{~m}$ and $48 \mathrm{~m}$ above the section base regarding ammonoid occurrences. In the field, we found Nowakia barrandei in the interval from $21 \mathrm{~m}$ to $35 \mathrm{~m}$, which is consistent with this interpretation. This argument goes in favour of placing the Daleje Event in the upper position, supported by finer grained facies, which is more pelagic than in lower layers.

Evidence for slumping might indicate synsedimentary tectonics; it is unclear to what degree these mass movements have been activated by tectonic movements linked with the closure of the Turkestan Ocean (for references see Loury et al. 2018). The range of other fossils as well as ammonoid assemblages suggests that these sections are not condensed. Furthermore, differences in preservation ranging from crushed fossils in shales to threedimensionally preserved specimens sometimes hamper comparisons. Nevertheless, the ammonoid taxa differ in abundance both vertically (stratigraphically) and horizontally (geographically). At first sight, the ammonoid associations appear somewhat chaotic and it is not easy to infer a biostratigraphic sequence. Concerning the section Shirdag South, placing the level of the Daleje Event at around $88-90$ metres above section base is better supported by index fossils. The three taxa Kitabobactrites salimovae, Metabactrites rakhmonovi and Beckeroceras khanakasuense appeared before the Daleje Event, because we found K. salimovae and Becker et al. (2010) also recorded the other two taxa at Khodzha Kurgan below this event. The microfacies and accompanying faunas could suggest a slightly more proximal localization for Shirdag and more distal for Khodzha Kurgan. The poor 


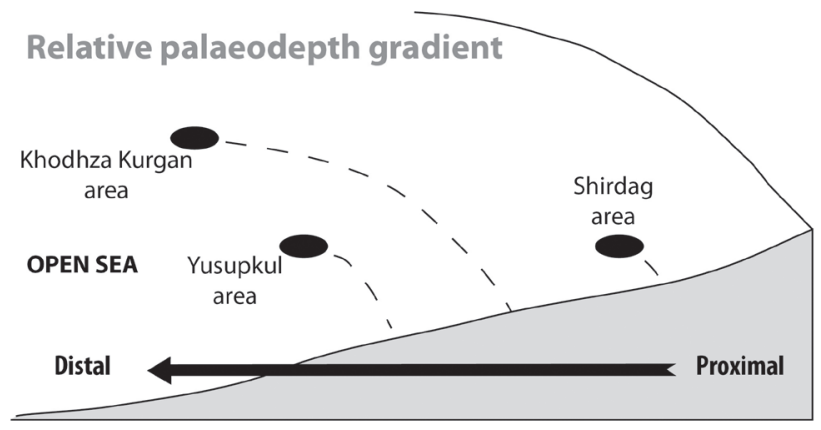

Figure 14. Relative palaeodepth gradient for the three investigated localities in Kitab. According to our data and results, we think that Shirdag had a more proximal position compared to Khodza Kurgan and Yusupkul in a more distal environment.

outcrop quality (largely overgrown) of Yusupkul likely reflects a higher clay content and thus suggests a more pelagic facies (Fig. 14). Additionally, the ammonoid and dacryoconarid assemblages place most of this section in the lower part of the Dzhaus Beds below the Daleje Event.

\section{Ammonoid zonation}

The ammonoids were initially discovered in the Kitab region by A.I. Kim in 1957 and jointly examined with H.K. Erben. Some of these taxa were figured (then as nomina $n u d a$ ) in the field guide to the 1978 SDS meeting by Kim et al. (1978), where they also listed their stratigraphic position. These were described in detail by Bogoslovsky $(1980,1984)$. Some of this material was revised by Yatskov (1990) and Becker et al. (2010); the latter authors reported some new material discovered and refined some of the ranges tabulated in Yolkin et al. (2008). Here, we describe additional material from the Khodza-Kurgan Gorge and from additional sections that we collected. In total, we recorded 13 taxa. Since Gaurites sperandus Bogoslovsky, 1984 occurs only in the Yusupkul section, which is not presented in the synthetic figure (Fig. 4), this taxon has been excluded from the Unitary Association analysis, because it provided one UA itself, which was logically not found in other sections and therefore not useful for correlations. We found four main Unitary Associations (UAs) in the sampled interval. The taxa included in each UAZ are summarized in Tab. 1.

The first UA-zone (UAZ 1 - Tab. 1, Fig. 4) contains seven taxa. E. advolvens is the only species characteristic for this UA. This UA is found in all sections except the Khodzha-Kurgan, which is explained by the fact that E. advolvens has not been found in this section yet. Nevertheless, it is most likely that the assemblage at the base of the section (ammonoid occurrences of the first 25 metres) belongs to this first UA. Concerning the Khodzha-Kurgan West section, it is likely that the entire ammonoid record is dominated by this UAZ 1 , because when correlating this section with the Khodzha-Kurgan section across the stream (less than $100 \mathrm{~m}$ apart), it is mostly this lower part that is exposed.

The second UA-zone (UAZ 2 - Tab. 1, Fig. 4) list seven taxa for this zone as well. It consists of the same taxa as UAZ 1 with the exceptions that Teicherticeras $\mathrm{cf}$. planum is present and Erbenoceras advolvens is absent. As $T$. cf. planum has been found in only one bed and in one section, this UA occurs therefore only once in the section Shirdag South, around the $67 \mathrm{~m}$ above base.

The third UA-zone (UAZ 3 -Tab. 1, Fig. 4) comprises eight taxa and was found in Khodzha Kurgan and Shirdag North sections only. $U$. rudicostatus is the index species of this assemblage. U. rudicostatus was not found in the Shirdag South section yet. Therefore, the middle part of the section cannot be correlated using this method to any other section.

The fourth UA-zone (UAZ 4 - Tab. 1, Fig. 4) is the last of the UAZs and was only found in the Shirdag South section. Thus, this UAZ is not informative for the correlation of our sections. We suspect that this zone is also present in the upper part of the Khodza-Kurgan Gorge as Becker et al. (2010) did recover both B. khanakasuense and M. rakhmonovi (their "? Metabactrites sp.") in their Unit 16 - 28-29m above the base of the Khodza-Korgan Gorge section.

With the available ammonoid-data, the Unitary Association method did not provide support for the correlation. It is not entirely clear, whether the low resolution of the correlation is related to a sampling bias or another cause such as a facies control and synsedimentary tectonics that disturbed the primary order of appearances of ammonoids or the overall stability of ammonoid occurrences in this region or a combination of these biases.

\section{Ammonoid succession and the Daleje ammonoid turnover}

To better understand the ammonoid succession, focusing on the Khodza-Kurgan Gorge makes the most sense as it provides the most complete Emsian ammonoid record of Uzbekistan (Becker et al. 2010). Comprehensive sampling of the thick monotonous sequences of the KhodzaKurgan Gorge is a challenge because of fluctuations in fossil abundance, fossil preservation, sedimentary facies and locally unclear tectonic structures. Nevertheless, if we combine our biostratigraphic data from the KhodzaKurgan Gorge with previous studies and correlate it with the existing dacryoconarid zonation, the picture becomes clearer.

The oldest ammonoids (Erbenoceras sp., Gyroceratites sp.) in the Khodza-Kurgan Gorge were previously reported from the upper part of the Norbonak Beds (Unit 11; 
Kim et al. 1978); they co-occur with Nowakia zlichovensis and predate the base of the Now. barrandei dacryoconarid Zone (Yolkin et al. 2008, Kim et al. 2012). These ammonoids resemble Erbenoceras advolvens or E. kimi and Gyroceratites cf. heinricherbeni De Baets et al., 2013, but given their poor preservation and lack of newly discovered material, it is currently not possible to be sure about their taxonomic assignments.

In other sections such as those at Shirdag, Erbenoceras kimi, E. advolvens and Gyroceratites sp. (heinricherbeni or laevis) belong to the oldest ammonoids. Sometimes, they might already be associated with Ivoites meshchankinae. Note that previous unfigured reports of E. kimi (s.l.) cannot always be taken at face value because two taxa were described as E. kimi, which are now assigned to two different genera (E. kimi, Beckeroceras khanakasuense) and because some poorly preserved fragments previously attributed to Erbenoceras kimi might actually belong to $E$. advolvens - herein reported for the first time from Uzbekistan. E. advolvens was occasionally reported as $E$. cf. solitarium from the southern Tien Shan (Nikolaeva et al. 2017) and is also known from the Urals (Bogoslovsky 1963, 1969; De Baets et al. 2013b).

In the Zeravshan Mountains, the most diverse ammonoid assemblages are known from the Dzhaus Beds, mostly covering the Nowakia barrandei to the lowermost parts of the Now. cancellata Zone (Becker et al. 2010, Kim et al. 2012). These provide a unique opportunity to study changes in ammonoid assemblages in layers rich in ammonoids across the Zlíchov and Daleje transgressions. House (1985) defined the beginning of the Daleje transgression by the disappearance of auguritids and some mimosphinctids, but regarding biostratigraphic data from Morocco and various other regions (including the type region), these changes might be more gradual (Ferrová et al. 2012, Klug 2017). This is of interest for the definition of the subdivision of the Emsian with proposals ranging for the placement between the Now. barrandei and Now. elegans zones (Ferrová et al. 2012, Tonarová et al. 2017, which would correspond to the Zlíchov Event according to Aboussalam et al. 2015) to its placement between the Now. elegans and Now. cancellata zones (at the traditional Daleje Event: Chlupáč \& Kukal 1986, House 1985).

Traditionally, the boundary was linked with the disappearance of the Anetoceras fauna (sensu Chlupáč 1976), although the Ivoites fauna might be the more appropriate name as it is probably the only genus, which is distributed throughout almost the entire early Emsian. Anetoceras, as revised by De Baets et al. (2009, 2013b), currently comprises coarsely ribbed, gyroconical forms. Finely ribbed, more loosely coiled forms completing fewer whorls are now described as Ivoites. Difficulties arise when one tries to verify older unfigured reports of Anetoceras as they could possibly also represent finely ribbed Ivoites or coarsely ribbed, more tightly coiled Erbenoceras. If the disappareance of the Anetoceras fauna, i.e. of representatives of the Anetoceratinae (Erbenoceras, Ivoites) and Auguritidae (Celaeceras, Kimoceras), remains an important marker for the subdivision of the Emsian, the transition from the Now. elegans Zone to the Now. cancellata Zone is the most important change at least when considering changes in the in ammonoid fauna in the Zeravshan Mountains. Still, ammonoid taxa traditionally used to date this turnover disappear before this event in the Zeravshan, while other taxa persist into the basalmost Now. cancellata Zone (Ivoites in the Khodza-Kurgan Gorge) where Now. elegans is still reported (Becker et al. 2010).

Peculiarly, there are no marked changes in ammonoid assemblages across the barrandei to elegans Zone in the Khodza-Kurgan Gorge. Many taxa cross this boundary including Mimosphinctes bipartitus, M. erbeni (auct.), and Uzbekisphinctes rudicostatus. Erbenoceras kimi is the most common taxon while its counterpart Beckeroceras khanakasuense could only be found higher up the sections above the first occurrence of true E. kimi in the Now. elegans Zone. Erbenoceras kimi is not restricted to Uzbekistan, but has also been reported from other localities in the South Tien Shan (Bardashev et al. 2005, Nikolaeva et al. 2017). We did not find the association Kimoceras lentiforme and B. khanakasuense during our field work in the KhodzaKurgan Gorge, but it was previously reported from Unit 16 in Becker et al. (2010), thus allowing to correlate our new in-situ finds in Shirdag with the Khodza-Kurgan Gorge. Both E. kimi and B. khanakasuense as well as $K$. lentiforme disappear slightly below the first appearance of Nowakia cancellata. In most localities, Ivoites and auguritids (Gaurites sperandus, K. lentiforme) disappear in the basalmost Now. cancellata Zone (where there is still an overlap with $N$. elegans), if our correlations in Khodza-Kurgan with previous dacryoconarid studies are correct (Yolkin et al. 2008, Kim et al. 2012). Ivoites might still occur there slightly above the last occurrence of Nowakia elegans but disappears before the end of the Now. cancellata Zone. Gyroceratites laevis, Uzbekisphinctes rudicostatus and Mimagoniatites fecundus disappear only shortly below the base of the Obisafit Beds, but they are still present in the Now. cancellata Zone. Ammonoids re-appear above the base of the Now. richteri Zone with specimens assigned to Crispoceras cf. crispi Chlupáč \& Turek, 1983 and Mimagoniatites cf. bohemicus Barrande, 1865 in Unit 31 as well as "Latanarcestes" sp. in bed 32 (Kim et al. 1978, Yolkin et al. 2008). The largest drop in diversity therefore corresponds to the transition from the Now. elegans to Now. cancellata Zone in Uzbekistan, which does not correspond to marked changes in facies.

If we project previous findings in our section (KKG with uncertainties) and additional finds from other sections (all sections with uncertainties), this pattern changes very 
slightly (Fig. 15). Yolkin et al. (2008) reported the last occurrences of coarsely ribbed Mimosphinctes tripartitus in the Now. elegans Zone, while M. erbeni (auct.) is potentially still present lowermost Now. cancellata Zone, too. A new species has to be erected of the latter as the holotype is probably not conspecific with the Uzbek material (Becker et al. 2010, Klug 2017), but as we did not find additional material, we refrained from erecting a new species. A similar pattern is obtained when we compile previously reported occurrences described from other localities with respect to dacryoconarid zonation. According to an unpublished report and own findings, Gaurites cooccurs with Nowakia barrandei and disappears before the Now. elegans Zone in Yusupkul Stow and KhodzaKurgan Gorge. Erbenoceras kimi as well as Beckeroceras khanakasuense might be potentially better index species, which disappear before the Now. cancellata Zone, while Ivoites meshchankinae seemingly only disappears above its base. A stratigraphically very low report by Yolkin et al. (2008, their Bed $15-5 \mathrm{~m}$ ) of E. kimi, M. erbeni (auct.), $M$. tripartitus and $U$. rudicostatus could not be reproduced. It might correspond to the provenance of the assemblage containing Teicherticeras planum Bogoslovsky, 1980, which we did not find during our fieldwork in KhodzaKurgan Gorge. We did find specimens of Teicherticeras cf. planum in Shirdag, which are associated with G. laevis, E. kimi, C. flexuosum, M. fecundus, I. meshchankinae and $K$. lentiforme and fall into the Now. barrandei zone.

The assignments of the ammonoids, which are not refigured, are hard to verify as multiple taxa have been confused with one another. For example, some of the specimens previously attributed to Gyroceratites laevis might actually represent $G$. heinricherbeni, which is more loosely coiled and has a larger umbilical window than G. laevis (De Baets et al. 2013b), although their separation is difficult in poorly preserved specimens when their early ontogeny and thus the umbilical window is not preserved. Another issue is the potential confusion of Beckeroceras khanakasuense with Erbenoceras kimi (to which some of its type material was previously assigned) or superficial resemblance of poorly preserved specimens of Mimosphinctes erbeni (auct.), Uzbekisphinctes rudicostatus or M. tripartitus.

Some taxa disappear before the last occurrence of $\mathrm{No}$ wakia elegans. Overall, major changes and many genera typical for the Zlichovian disappear at the end of the Now. elegans or at the beginning of the Now. cancellata Zone in Uzbekistan and beyond. Gaurites appears to have a limited stratigraphic range, but Kimoceras is more widely distributed and only disappears in the basal part of the Now. cancellata Zone in the Khodza-Kurgan Gorge. Derived auguritids (Celaeceras) are still present in the Now. elegans Zone in Spain (Montesinos \& Garcia-Alcalde 1996) and potentially also in the Barrandian (Chlupáč \&
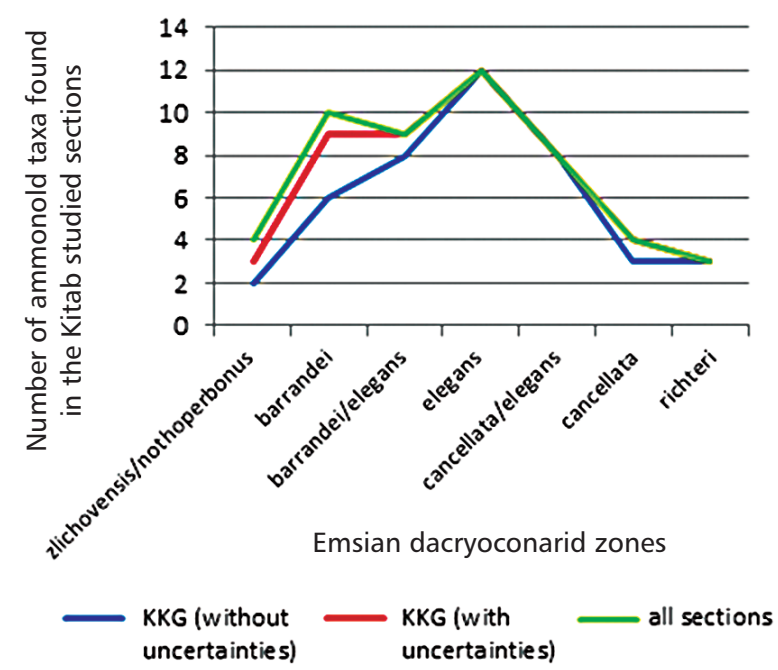

Figure 15. Number of ammonoid taxa in each dacryoconarid zonation (in the Kitab Geological Reserve).

Turek 1983). Gaurites mirandus might even be present in the basal Now. cancellata Zone in the Urals. Ivoites meshchankinae is reported from the Now. barrandei Zone to the basalmost Now. cancellata Zone. Similarly, small Ivoites are thought to be restricted to the elegans Zone in China (Ruan 1996) and Bohemia (Chlupáč et al. 1979, Chlupáč \& Lukeš 1999).

For the time being, it appears therefore reasonable to keep the Daleje Event (s. str.) as the primary marker for an early-late Emsian substage boundary and not other, much lower levels such as the base of the Eolinguipolygnathus nothoperbonus Zone or the level of the Upper Zlíchov Event, including the base of the Now. elegans Zone. If the ammonoid turnover remains an important target for its definition, it should be preferentially studied in regions where there is a continuous and diverse ammonoid record without marked facies changes across these events like in South China or Uzbekistan. In this respect, the Anti-Atlas, the Rhenish Massif and Bohemia are somewhat less informative because the ammonoid faunas differ in ranges or are of lower diversity across this transition and might also underly certain sampling and preservational biases (Klug 2017). The Uzbek ammonoid assemblages are reminiscent of several early ammonoid faunas reported from South China (Xian et al. 1980, Ruan 1981, Yu \& Ruan 1988) interpreted to be mainly deposited on the middle to lower "slope" (Ruan 1996). However, their stratigraphic provenance and taxonomy is poorly documented and in need of revision. As these faunas also contain various anetoceratids, mimosphinctids and oxyconic forms, these might be of great interest for a detailed correlation with Uzbekistan and disentangling changes in ammonoid diversity throughout the Emsian.

The youngest auguritids mostly disappear within the Now. elegans Zone; they are quite rare, which might indicate facies controls on their distribution. As these forms 
are widely distributed palaeogeographically (Monnet et al. 2011b), they might represent more pelagic forms. Anetoceratinae probably disappeared globally between the end of the Now. elegans Zone (e.g. Erbenoceras) and the beginning of the Now. cancellata Zone (e.g. Ivoites). More studies need to be carried out as Ivoites and various other gyroconically coiled ammonoids have often been overlooked or confused to establish if the disappearance happened more or less synchronously around the globe.

\section{Palaeogeography and ammonoid endemism}

Presuming that the palaeogeographic map of Scotese (2001) is accurate, the region of today's Zeravshan Mountains and other South Tien Shan localities (Sangibaland Mountain in Kyrgyzstan) were separated by large distances from other early Emsian ammonoid occurrences (Fig. 16) in southern China (Guangxi: Shen 1975, Ruan 1981) and Vietnam in the southeast (Mansuy 1921), the Kolyma Basin in the northwest, the North Urals in the west (Bogoslovsky 1963), and the northern Caucasus in the south (Nikolaeva 2007).

It is striking that many of the ammonoid species described from Uzbekistan (Bogoslovsky 1969, 1972, 1984; Yatskov 1990; Bardashev et al. 2005; Kim et al. 2007; Becker et al. 2010) have only been described from this region. Meanwhile, Erbenoceras kimi has also been recorded from other South Tien Shan localities outside Uzbekistan including Sangibaland Mountain in Kyrgyzstan (Nikolaeva et al. 2017) and potentially also in the Alai Mountains in Turkestan (Kiselev \& Starshinin 1987), which were close to each other in the Early Devonian facing the passive margin of the Turkestan or South Tien Shan Ocean (Windley et al. 2007, Filippova et al. 2001, Nikolaeva et al. 2017).

Out of the fourteen species listed in Tab. 2, nine species $(60 \%)$ have not been recorded from other regions (i.e. outside the South Tien Shan Mountains) and thus appear to be endemic. This pattern is observed when just focusing on species reported from the Nowakia barrandei and Now. elegans zones, while endemicity seems less pronounced (about 30\%) in the Now. zlichovensis and Now. cancellata zones.

In terms of the number of shared species, four species have also been reported from Germany (e.g. Erben 1960; Göddertz 1987; De Baets et al. 2009, 2013a, b) and the Czech Republic (Barrande 1865-1877, Erben 1962, Chlupáč 1976), three each from China (Shen 1975; Ruan 1981, 1996), France (e.g. Erben 1960, Feist 1970), and Morocco (e.g., Petter 1959, Becker \& House 1994, Klug 2001, De Baets et al. 2010), two each from Spain (Montesinos \& Truyols-Massoni 1987, Montesinos \& Sanz López 1999, Truyols-Massoni 1999) and two regions of in Russia (Urals: Bogoslovsky 1963, 1969; Caucasus: Nikolaeva 2007) and only one each from Algeria (e.g. Göddertz 1989), Turkey (Bithynia: e.g. Göddertz 1987), and Vietnam (Mansuy 1921). This pattern seemingly suggests closer palaeobiogeographic relationships of the Zeravshan Mountain region to the Rhenish Massif or Bohemia. However, we suggest that this is an effect of the more intense research and sampling in Europe compared to, e.g. some regions in Asia. According to our own field observations in Guangxi (China; e.g. Shen 1975, Ruan 1981),

Figure 16. Palaeogeographic map of the Devonian by Scotese (2001), modified after a version by De Baets et al. (2009). Note the rather isolated position of the Uzbek ammonoid occurrences.

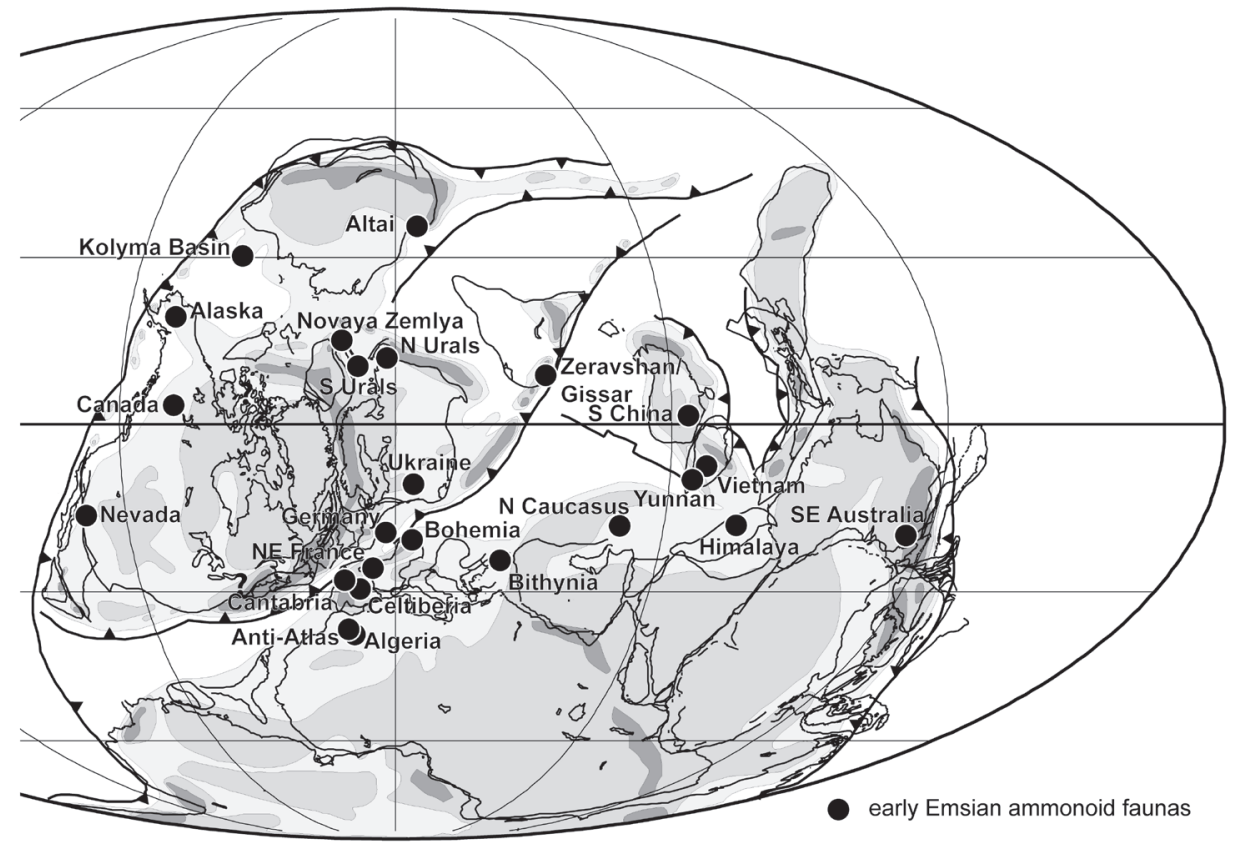


Table 2. Early Emsian ammonoids occurring in Uzbekistan (including other Tien Shan localities) and geographic occurrences of these taxa in other regions (data from the databases GONIAT (Kullmann 2011) and AMMON (Korn \& Ilg 2007). Some own records have been added. The asterisk indicates that a similar or identical species may occur in South China.

\begin{tabular}{|c|c|c|c|c|c|c|c|c|c|c|c|c|}
\hline Species & 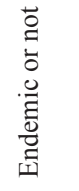 & 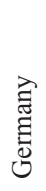 & 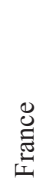 & 胥 & 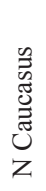 & $\begin{array}{l}\text { : } \\
\text { थี } \\
\text { की }\end{array}$ & 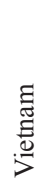 & $\begin{array}{l}\underset{\Xi}{\Xi} \\
\text { 己 } \\
\text { Un }\end{array}$ & $\begin{array}{l}\frac{\pi}{\Xi} \\
\frac{0}{0} \\
\frac{0}{0}\end{array}$ & $\begin{array}{l}\frac{\pi}{\vec{d}} \\
\frac{D}{4}\end{array}$ & 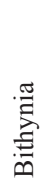 & 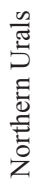 \\
\hline Metabactrites rakhmonovi & yes & & & & & & & & & & & \\
\hline Ivoites meshchankinae & no & & & & & & & $?$ & • & & & \\
\hline Erbenoceras advolvens & no & • & • & • & - & - & • & • & • & & $?$ & • \\
\hline Erbenoceras kimi & yes* & & & & & & $?$ & $?$ & & & & \\
\hline Uzbekisphinctes rudicostatus & yes & & & & & & & & & & & \\
\hline Beckeroceras khanakasuense & yes & & & & & & & & & & & \\
\hline Mimosphinctes tripartitus & no & • & & & & • & & & & & & \\
\hline Mimosphinctes erbeni (auct.) & yes & & & & & & & & & & & \\
\hline Gyroceratites laevis & no & • & • & - & & & & - & • & & & \\
\hline Mimagoniatites fecundus & no & • & • & - & $\cdot$ & & & $\cdot$ & • & • & $\cdot$ & \\
\hline Teicherticeras planum & yes & & & & & & & & & & & \\
\hline Kimoceras lentiforme & yes & & & & & & & & & & & \\
\hline Gaurites sperandus & yes & & & & & & & & & & & \\
\hline Convoluticeras flexuosum & yes & & & & & & & & & & & \\
\hline Number of shared species & & 4 & 3 & 3 & 2 & 2 & 1 & 3 & 4 & 1 & 1 & 1 \\
\hline
\end{tabular}

the Hunsrück (Germany; e.g. De Baets et al. 2009, 2013a, b), Bohemia (Czech Republic; e.g. Barrande 1865-1877; Chlupáč 1976; Chlupáč \& Turek 1977, 1983), and northern Africa (e.g. Göddertz 1987; Becker \& House 1994; Klug 2001, 2007), we predict that additional sampling would reveal closer faunal relationships of the South Tien Shan to Guangxi, Yunnan, and Vietnam than to what today belongs to Europe and northern Africa. This is supported by, for example, the absence of large Erbenoceras from Guangxi, Yunnan, and northeastern Vietnam and its presence in Central Europe and northern Africa as well as by the abundance of small advolute Erbenoceras (E. elegantulum Shen, 1975, E. kimi), small Ivoites (I. luofense Ruan, 1981, I. meshchankinae) and diverse mimosphinctids (Beckeroceras khanakasuense, Mimosphinctes bipartitus, M. erbeni (auct.), M. rotatile Ruan, 1981, Uzbekisphinctes discordans, U. rudicostatus) in Central and Southeast Asia. Of course, there are some almost cosmopolitan species such as Erbenoceras advolvens (Klug 2001; Korn \& Klug 2012; De Baets et al. 2013a, b), Gyroceratites laevis and particularly Mimagoniatites fecundus (which might encompass several species since it is overly lumped in our opinion).

It is remarkable that the oxyconic forms Kimoceras and Gaurites are both endemic. Gaurites was previously only reported from a restricted stratigraphic interval in one locality (one bed in the Now. barrandei Zone), but could now be recovered also from the Khodza-Kurgan Gorge and multiple beds in Yusupkul Stow. Kimoceras lentiforme is known from both Khodza-Kurgan and Shirdag and has a larger stratigraphic range (Becker et al. 2010).

The family Auguritidae with its close relatives is rather small and contains only a few genera (Gaurites, Celaeceras, Weyeroceras), which are known from regions that were moderately close to each other in the Emsian (Moroccan Anti-Atlas, Spain, Bohemia, North Urals; Barrande 1865-1877, Bogoslovsky 1969, Montesinos \& GarciaAlcalde 1996, Klug 2001, Korn \& Klug 2002, Kim et al. 2007, De Baets et al. 2010, Monnet et al. 2011b, Klug et al. 2015). Their absence in other regions might also relate to their rarity related with potential facies or sampling controls on their distribution. Furthermore, oxyconic forms (e.g. Daxinoceras, either an auguritid or a mimagoniatitid) have also been reported from South China (Xian et al. 1980), but are in need of revision.

\section{Conclusions}

(1) We documented the facies transition from the reefal facies of the Pragian to the pelagic facies of the early Emsian. The transition from massive reefal limestone of the Madmon Formation via moderately thin-bedded bioclastic layers of the Khukarian Beds to the more pelagic, thin-bedded and 
lightly siliceous carbonates of the Dzhaus Beds suggest a transgression. A mix of biostratigraphic uncertainties concerning the correlation of global transgressions and tectonic features prevent us from concluding on the mechanism that ended platform growth. At least, we found no evidence for emergence and good evidence for rising water depth.

(2) We describe the new enigmatic bactritid Kitabobactrites salimovae gen. et sp. nov. and several new ammonoid taxa. Ivoites meshchankinae sp. nov. and Metabactrites rakhmonovi sp. nov. are characterized by very loosely coiled conchs and densely spaced ribs. Beckeroceras gen. nov. and Uzbekisphinctes gen. nov. share the tightly coiled conchs with a strong ornamentation consisting of strong primary and weak secondary ribs.

(3) The largest ammonoid turnover is found at the transition from the Nowakia elegans to Now. cancellata zone, the level of the Daleje Event. This highlights the need for further work on deeper, more voluminous sections in South China and the Zeravshan Gissar in order to achieve better correlations and ultimately a meaningful subdivision of the Emsian.

(4) Superficially, it seems like there are more ammonoid taxa shared by early Emsian ammonoid faunas from Europe, Morocco and the Zeravshan Mountains than those from Central Asia and the palaeogeographically closer Southeast Asia (southern China, northeastern Vietnam). This likely roots in a sampling bias, because the European and Moroccan faunas are much better studied than those from Southeast Asia. This is corroborated by certain shared faunal elements such as small representatives of Erbenoceras and the abundance of Ivoites.

\section{Acknowledgements}

We cordially thank the late Utkir J. Rakhmonov (Shahrisabz) for his great hospitality and his important support in organizing our visits. Firuza Salimova and Natalya Meshchankina (Tashkent) both were of greatest help during the preparation of our visits; as far as our visits to the Kitab State Geological Reserve are concerned, the entire work would have been impossible without them. The field work and other project-related work was supported by the Swiss National Science Foundation (Project numbers 200020_132870 and 200020_149120); we greatly appreciate this support. We thank Catherine Crônier (Lille I) for providing maps, and Sebastien Clausen (Lille I) for helping with making thin sections. Furthermore, we thank Franziska Blattman (Zürich) for helping in the lab, and Maximiliano Meier (Bulle), David Ware (Berlin) and Nicolas Goudemand (Lyon) for helpful discussions about the UA-method. Svetlana Nikolaeva (London) and Dieter Korn (Berlin) kindly reviewed the manuscript and provided numerous valuable suggestions to improve it.

\section{References}

Aboussalam, Z.S., Becker, R.T., \& Bultynck, P. 2015. Emsian (Lower Devonian) conodont stratigraphy and correlation of the Anti-Atlas (Southern Morocco). Bulletin of Geosciences 90, 893-980. DOI 10.3140/bull.geosci.1534

Bardashev, I.A., Bardasheva, N.P., Weddige, K. \& Ziegler, W. 2005. Stratigraphy and facies of the Middle Paleozoic of parts of southern Tien-Shan in Tajikistan and Uzbekistan. Palaeobiodiversity and Palaeoenvironments 85, 319-364. DOI 10.1007/BF03043614

BARRANDE, J. 1848. Über die Brachiopoden der silurischen Schichten von Böhmen. Naturwissenschaftliche Abhandlungen 2, 367-475, 14-22 pls.

Barrande, J. 1865-1877. Systême Silurien du centre de la Bohême, I. Partie, Vol. II: Céphalopodes. 107 pls (1965), text xxxvi +712 pp. (1867), 461-544 pls (1877). Published by the author, Prague \& Paris.

Becker, R.T. \& House, M.R. 1994. International Devonian goniatite zonation, Emsian to Givetian, with new records from Morocco. Courier Forschungsinstitut Senckenberg, Willi Ziegler Festschrift II 169, 79-135.

Becker, R.T., De Baets, K. \& Nikolaeva, S. 2010. New ammonoids records from the lower Emsian of the Kitab Reserve (Uzbekistan) - preliminary results. SDS Newsletter 25, 20-28.

Berkyová, S., FrÝda, J., \& Lukeš, P. 2007. Unsuccessful predation on Middle Paleozoic plankton: Shell injury and anomalies in Devonian dacryoconarid tentaculites. Acta Palaeontologica Polonica 52, 407-412.

Bogoslovsky, B.I. 1961. Eifelian ammonoids of the Ural and question of classification of agoniatids. Paleontologicheskii Zhurnal 4, 60-70. [in Russian]

Bogoslovsky, B.I. 1963. Oldest Devonian Ammonoids of the Urals. Paleontologicheskii Zhurnal 1963(2), 26-37. [in Russian]

Bogoslovsky, B.I. 1969. Devonian ammonoids: I. Agoniatitids. Trudy Paleontologicheskogo Instituta Akademii Nauk SSSR 124, 1-341 + 109 pls. [in Russian]

Bogoslovsky, B.I. 1972. New Early Devonian cephalopods from Novoy Zemli Novaya Zemlya. Paleontologicheskii Zhurnal 4, 44-51. [in Russian]

Bogoslovsky, B.I. 1980. Early Devonian ammonoids of the Zeravshan Range. Paleontologicheskii Zhurnal 1980(4), 51-66. [in Russian]

BogoslovsKy, B.I. 1984. A new genus of the family Auguritidae and the ammonoids accompanying it from the Lower Devonian of the Zeravshan Range. Paleontologicheskii Zhurnal 1984 (1), 30-36. [in Russian]

Botquelen, A., Gourvennec, R., Loib, A. \& Le Menn, J. 2001. Relations entre les variations des assemblages benthiques emsiens et l'eustatisme dans la coupe de Seillou (Massif armoricain, France). Comptes Rendus Académie des Sciences Paris, Sciences de la Terre et des planètes / Earth and Planetary Sciences 332, 45-50. DOI 10.1016/S1251-8050(00)01496-8

BoUČEK, B. 1964. The tentaculites from Bohemia. Their morphology, taxonomy, ecology, phylogeny and biostratigraphy. 215 pp. Publishing House of the Czechoslovak Academy of Sciences, Prague.

Brunet, M.-F., McCann, T. \& Sobel, E.R. 2017. Geological 
Evolution of Central Asian Basins and the Western Tien Shan Range. Geological Society, London, Special Publications 427, 1-17. DOI 10.1144/SP427.17

Carls, P. \& Valenzuela-Ríos, J.I. 2002. Devonian-Carboniferous rocks from the Iberian Cordillera. Cuadernos des Museo Geominero 1, 299-414.

Carls, P., Slavík, L. \& Valenzuela-Ríos, J.I. 2008. Comments on the GSSP for the basal Emsian stage boundary: the need for its redefinition. Bulletin of Geosciences 83, 383-390. DOI 10.3140/bull.geosci.2008.04.383

Chlupéč, I. 1976. The oldest goniatite faunas and their stratigraphic significance. Lethaia 9, 303-315. DOI 10.1111/j.1502-3931.1976.tb01326.x

Chlupáč, I. \& Kukal, Z. 1986. Reflection of possible global Devonian events in the Barrandian area, C.S.S.R, 169-179. In Walliser, O.H. (ed.) Global Bio-Events, Lecture Notes in Earth Sciences 8. DOI 10.1007/BFb0010202

Chlupéč, I., \& KuKal, Z. 1988. Possible global events and the stratigraphy of the Palaeozoic of the Barrandian (CambrianMiddle Devonian, Czechoslovakia). Sbornik geologických věd, Geologie 43, 83-146.

CHLUPÁČ, I. \& LuKEš, P. 1999. Pragian/Zlíchovian and Zlíchovian/ Dalejan boundary sections in the Lower Devonian of the Barrandian area, Czech Republic. Newsletter on Stratigraphy, 75-100. DOI 10.1127/nos/37/1999/75

Chlupéč, I. \& Turek, V. 1977. New cephalopods (Ammonoidea, Bactritoidea) from the Devonian of the Barrandian area, Czechoslovakia. Věstník Ústředního ústavu geologického 52, 303-306.

Chlupéč, I. \& Turek, V. 1983. Devonian goniatites from the Barrandian area. Czechoslovakia. Rozpravy Ústředního ústavu geologického 46, 1-159.

Chlupéč, I., Lukeš, P., \& Zikmundová, J. 1979. The Lower/ Middle Devonian boundary beds in the Barrandian area, Czechoslovakia. Geologica et Palaeontologica 13, 125-156.

Crônier, C. \& Tsmeyrek, H.S. 2010. First Record of the Devonian Phacopid Trilobite 'Plagiolaria' from Uzbekistan. Memoirs of the Association of Australasian Palaeontologists 39, 43-50.

CUVIER, G. 1797. Tableau élémentaire de l'histoire naturelle des animaux. 710 pp. Baudouin, Paris.

DOI 10.5962/bhl.title.45918

De Baets, K., Klug, C. \& Korn, D. 2009. Anetoceratinae (Ammonoidea, Early Devonian) from the Eifel and Harz Mountains (Germany), with a revision of their genera. Neues Jahrbuch für Geologie und Paläontologie, Abhandlungen 252, 361-376. DOI 10.1127/0077-7749/2009/0252-0361

De Baets, K., Klug, C. \& Korn, D. 2011. Devonian pearls and ammonoid-endoparasite coevolution. Acta Palaeontologica Polonica 56, 159-180. DOI 10.4202/app.2010.0044

De Baets, K., Klug, C. \& Plusquellec, Y. 2010. Zlíchovian faunas with early ammonoids from Morocco and their use for the correlation between the eastern Anti-Atlas and the western Dra Valley. Bulletin of Geosciences 85(2), 317-352. DOI 10.3140/bull.geosci.1172

De Baets, K., Goolaerts, S., Rietbergen, T. \& Klug, C. 2013 a. The first record of Early Devonian ammonoids from Belgium and their significance. Geologica Belgica 16, 148-156.

De Baets, K., Klug, C., Korn, D., Bartels, C. \& Poschmann, M. 2013b. Emsian Ammonoidea and the age of the Hunsrück Slate
(Rhenish Mountains, Western Germany). Palaeontographica A 299, 1-114. DOI 10.1127/pala/299/2013/1

De Baets, K., Klug, C., Korn, D. \& Landman, N.H. 2012. Early evolutionary trends in ammonoid embryonic development. Evolution 66, 1788-1806.

DOI 10.1111/j.1558-5646.2011.01567.x

Dunham, R.J. 1962. Classification of carbonate rocks according to depositional texture, 108-121. In HAM, W.E. (ed.) Classification of Carbonate Rocks. American Association of Petroleum Geologists Memoir 1.

Eichenberg, W. 1931. Die Schichtenfolge des HerzbergAndreasberger Sattelzuges. Neues Jahrbuch für Mineralogie, Geologie und Paläontologie, Beilage-Band B 65, 141-196.

Embry, A.F. \& Klovan, J.E. 1971. A late Devonian reef tract on northeastern Banks Island, N.W.T. Bulletin of Canadian Petroleum Geology 19, 730-781.

Erben, H.K. 1953. Goniatitacea (Ceph.) aus dem Unterdevon und Unteren Mitteldevon. Neues Jahrbuch für Geologie und Paläontologie, Abhandlungen 98, 175-225.

Erben, H.K. 1960. Primitive Ammonoidea aus dem Unterdevon Frankreichs und Deutschlands. Neues Jahrbuch für Geologie und Paläontologie, Abhandlungen 110, 1-128.

ERBEN, H.K. 1962. Über böhmische und türkische Vertreter von Anetoceras (Ammon., Unterdevon). Paläontologische Zeitschrift 36, 14-27. DOI 10.1007/BF02989625

ERBEN, H.K. 1965. Die Evolution der ältesten Ammonoidea. II. Neues Jahrbuch für Geologie und Paläontologie, Abhandlungen 122, 275-312.

Ennst, H.U. \& Klug, C. 2011. Perlboote und Ammonshörner Weltweit. Nautilids and Ammonites Worldwide. 224 pp. Pfeil, München.

FeIST, R. 1970. Présence d'Anetoceras (Erbenoceras) mattei n. sp. (Ammonoidée primitive) dans le Dévonien inférieur de la Montagne Noire. Comptes Rendus Hebdomadaires des Séances de l'Academie des Sciences, Serie D: Sciences Naturelles 270, 290-293.

Ferrová, L., Frýda, J. \& Lukeš, P. 2012. High-resolution tentaculite biostratigraphy and facies development across the Early Devonian Daleje Event in the Barrandian (Bohemia): implications for global Emsian stratigraphy. Bulletin of Geosciences 87, 587-624. DOI 10.3140/bull.geosci.1336

Filippova, I., Bush, V. \& Didenko, A. 2001. Middle Paleozoic subduction belts: the leading factor in the formation of the Central Asian fold-and-thrust belt, Russian Journal of Earth Sciences 3, 405-426. DOI 10.2205/2001ES000073

GöDDERTZ, B. 1987. Devonische Goniatiten aus SW-Algerien und ihre stratigraphische Einordnung in die Conodonten-Abfolge. Palaeontographica A 197, 127-220.

GöDDERTZ, B. 1989. Unterdevonische hercynische Goniatiten aus Deutschland, Frankreich und der Türkei. Palaeontographica A 208, 61-89.

GuEX, J. 1991. Biochronological Correlations. 252 pp. Springer Verlag, Berlin. DOI 10.1007/978-3-642-76583-4

Guex, J. \& Davaud, E. 1984. Unitary associations method: use of graph theory and computer algorithm. Computers and Geosciences 10, 69-96. DOI 10.1016/0098-3004(84)90007-4

HAMmer, Ø., Harper, D.A.T. \& RyAN, P.D. 2001. PAST: paleontological statistics software package for education and data analysis. Palaeontologia Electronica 4, 9. 
HaQ, B.U. \& Schutter, S.R. 2008. A chronology of Paleozoic sealevel changes. Science 322, 64-68.

DOI 10.1126/science.1161648

Holzapfel, E. 1895. Das Obere Mitteldevon (Schichten mit Stringocephalus Burtini und Maeneceras terebratum) im Rheinischen Gebirge. Abhandlungen der Königlich Preussischen Geologischen Landesanstalt, Neue Folge 16, 1-459.

House, M.R. 1985. Correlation of mid-Palaeozoic ammonoid evolutionary events with global sedimentary perturbations. Nature 213, 17-22. DOI 10.1038/313017a0

House, M.R. 1996. Juvenile goniatite survival strategies following Devonian extinction Events. In HART, W. (ed.) Biotic recovery from Mass Extinction Events. Geological Society Special Publication 102, 163-186.

DOI 10.1144/GSL.SP.1996.001.01.12

Hyatt, A. 1883-1884. Genera of fossil cephalopods. Proceedings of the Boston Society of Natural History 22, 253-338.

Izokh, N., Yolkin, E., Weddige, K., Erina, M., \& ValenzuelaRíos, J. 2011. Late Pragian and Early Emsian conodont polygnathid species from the Kitab state geological reserve sequences (Zeravshan-Gissar mountainous area, Uzbekistan). Geologiya i Geofizika 15, 49-63.

Johnson, J.G., Klapper, G. \& Sandberg, C.A. 1985. Devonian eustatic fluctuations in Euramerica. Geological Society of America Bulletin 96, 567-587. DOI 10.1130/0016-7606(1985)96<567:DEFIE >2.0.CO;2

Kim, A.I., Yolkin, E.A., Erina, M.V. \& Gratsianova, R.T. 1978. Type sections of the Lower and Middle Devonian boundary sediments in Middle Asia. A Guide to Field Excursions, Field Session of the International Subcommission on the Devonian Stratigraphy. 48 pp. 78 pls, Samarkand (Tashkent).

Kim, A.I., Salimova, I.A., Kim, N.A. \& Meshchankina, N.A. 2007. Palaeontological Atlas of Phanerozoic Faunas and Floras of Uzbekistan, Volume I: Palaeozoic (Cambrian, Ordovician, Silurian, Devonian, Carboniferous, Permian). 261 pp. Republic of Uzbekistan State Committee on Geology and Mineral Resources, Tashkent.

Kim, A.I., Erina, M.V., Kim, I.A., Salimova, F.A., Meshchankina, N.A. \& Rakhmonov, U.D. 2012. The Pragian-Emsian event and subdivision of the Emsian in the Zinzilban and KhodzhaKurgan sections. SDS Newsletter 27, 38-41.

KiseleV, G. \& Starshinin, D. 1987. Middle Palaeozoic cephalopod mollusks of the south Tian-Shan. Vestnik Sankt-Petersburgskogo Universiteta, Seriya 7, Geologiya i Geografiya 3, 84-88.

KLeIn, C. \& Korn, D. 2015. Quantitative analysis of the late Famennian and early Tournaisian ammonoid stratigraphy. Newsletters on Stratigraphy 49, 1-26. DOI $10.1127 /$ nos $/ 2015 / 0068$

KLUG, C. 2001. Early Emsian ammonoids from the eastern AntiAtlas (Morocco). Paläontologische Zeitschrift 74, 479-515. DOI 10.1007/BF02988158

KLUG, C. 2017. First description of the Early Devonian ammonoid Mimosphinctes from Gondwana and stratigraphical implications. Swiss Journal of Palaeontology 136, 345-358. DOI 10.1007/s13358-017-0138-5

Klug, C. Kröger, B., Rücklin, M., Korn, D., Schemm-Gregory, M., De Baets, K. \& Mapes, R.H. 2008. Ecological change during the early Emsian (Devonian) in the Tafilalt (Morocco), the origin of the Ammonoidea, and the first African pyrgo- cystid edrioasteroids, machaerids and phyllocarids. Palaeontographica A 283, 1-94.

DOI $10.1127 /$ pala/283/2008/83

Klug, C., Kröger, B., Vinther, J., Fuchs, D. \& De Baets, K. 2015. Ancestry, origin and early evolution of ammonoids, 3-24. In Klug, C., Korn, D., De Baets, K., Kruta, I. \& MAPES, R.H. (eds) Ammonoid paleobiology, Volume II: from macroevolution to paleogeography. Topics in Geobiology 44. Springer, Dordrecht. DOI 10.1007/978-94-017-9633-0_1

Korn, D. 2001. Morphometric evolution and phylogeny of Palaeozoic ammonoids. Early and Middle Devonian. Acta Geologica Polonica 51, 193-215.

Korn, D. 2014. Armatites kaufmanni n. sp., the first Late Devonian goniatite with ventral spines. Neues Jahrbuch für Geologie und Paläontologie Abhandlungen 271, 349-352. DOI 10.1127/0077-7749/2014/0393

Korn, D. \& ILG, A. 2007. AMMON. www.wahre-staerke.com/ammon/ Korn, D. \& KLug, C. 2002. Ammoneae Devonicae. - Fossilium Catalogus I: Animalia 138. 375 pp. Backhuys Publishers, Leiden.

Korn, D. \& KLug, C. 2012. Palaeozoic ammonoids - diversity and development of conch morphology, 491-534. In TALENT, J. (ed.) Extinction intervals and biogeographic perturbations through time: Earth and Life (International Year of Planet Earth). Springer, Netherlands. DOI 10.1007/978-90-481-3428-1_15

Korn, D., Mapes, R.H. \& Klug, C. 2014. The massive wrinkle layer of an Early Carboniferous ammonoid from Morocco. Palaeontology 57, 771-781. DOI 10.1111/pala.12087

KRÖGER, B. 2005. Adaptive evolution in Paleozoic coiled cephalopods. Paleobiology 31, 253-268. DOI 10.1666/0094-8373(2005)031[0253:AEIPCC]2.0.CO;2

Kröger, B., Vinther, J. \& Fuchs, D. 2011. Cephalopod origin and evolution: A congruent picture emerging from fossils, development and molecules. BioEssays 33, 602-613.

KuLLMANN, J. 2011. GONIAT. http://www.goniat.org. DOI 10.1002/bies.201100001

Lardeux, H., Morzadec, P., Bultynck, P. \& Walliser, O.H. 1979. La Grange Limestone, Massif Armoricain. Field Excursion Guidebook, 5-7.

Loury, C., Rolland, Y., Guillot, S., Lanari, P., Ganino, C., Melis, R., Jourdon, A., Petit, C., Beyssac, O., Gallet, S. \& Moni, P. 2018. Tectonometamorphic evolution of the Atbashi high-P units (Kyrgyz CAOB, Tien Shan): Implications for the closure of the Turkestan Ocean and continental subductionexhumation of the South Kazakh continental margin. Journal of Metamorphic Geology, 1-27. DOI 10.1111/jmg.12423

LuKEš, P. 1977. Some index tentaculites (Nowakiidae) from the Lower/Middle Devonian boundary beds of the Barrandian. Časopis pro mineralogii a geologii 22, 19-28.

Machel, H.G. \& Hunter, I.G. 1994. Facies Models for Middle to Late Devonian Shallow-marine Carbonates, with Comparisons to Modern Reefs: a Guide for Facies Analysis. Facies 30, 155-176. DOI 10.1007/BF02536895

Malygina, A.A. \& SAPELniKov, V.P. 1973. Silurijskie, rannedevonskie I eifelskie Pentamerida juzhnogo Tjan-Shanja. Trudy Instituta Geol. Geogr. Ural. Nauch. Cent. AN SSSR 104, 1-212.

Mansuy, H. 1921. Description de fossiles des terrains Paléozoïques et Mésozoïques du Tonkin septentrional (feuilles de Cao-Bang, de Ha-Lang, de That-Khe et de Lang-Son). Mémoires du Service Géologique de l'Indochine 8(1), 11-27. 
Miller, A.K. 1938. Devonian ammonoids of America. Geological Society of America, Special Papers 14, 1-262.

DOI 10.1130/SPE14-p1

Monnet, C., Klug, C. \& De Baets, K. 2011b. Parallel evolution controlled by adaptation and covariation in ammonoid cephalopods. BMC Evolutionary Biology 11, 1-21.

DOI 10.1186/1471-2148-11-115

Monnet, C., Klug, C., Goudemand, N., De Baets, K. \& Bucher, H. 2011a. Quantitative biochronology of Devonian ammonoids from Morocco and proposals for a refined unitary association method. Lethaia 44, 469-489.

DOI 10.1111/j.1502-3931.2010.00256.x

Montesinos, J.R. \& Garcia-Alcalde, J.L. 1996. An occurrence of the auguritid ammonoid Celaeceras in the Lower Devonian of northern Spain. Palaeontology 39, 149-155.

Montesinos, J.R. \& SAnz López, J. 1999. Ammonoideos del Devónico Inferior y Medio en el Pirineo Oriental y Central. Antecedentes históricos y nuevos hallazgos. Revista Española Paleontología, $N^{o}$ extr. Homenaje Prof. J.Truyols, 97-108.

Montesinos, J.R. \& Truyols-Massoni, M. 1987. La Fauna de Anetoceras y el límite Zlichoviense-Dalejense en el Dominio Palentino (NO. de España). Cuaderno Laboratorio Xeolóxico de Coruña 11, 191-208.

Nikolaeva, S. 2007. Discovery of Emsian Ammonoids in the Northern Caucasus. Paleontologicheskii Zhurnal 2007 (5), 34-39. [in Russian] DOI 10.1134/S003103010705005X

Nikolaeva, S., Kim, A. \& Erina, M. 2017. An early Emsian (Zlichovian) ammonoid assemblage from Sangibaland Mountain (Shakhimardan River Basin) (South Tien Shan, Kyrgyzstan). Palaeobiodiversity and Palaeoenvironments 97(3), 405-417. DOI 10.1007/s12549-017-0291-2

Petter, G. 1959. Goniatites Dévoniennes du Sahara. Publications du Service de la Carte Géologique de l'Algérie, Nouvelle Série, Paléontologie 2, 1-313.

Pickering, K.T., Koren, T.N., Lytochkin, V.N. \& Siveter, D.J. 2008. Silurian Devonian active-margin deep-marine systems and palaeogeography, Alai Range, Southern Tien Shan, Central Asia. Journal of the Geological Society 165, 189-210. DOI 10.1144/0016-76492006-082

RichteR, R. 1854. Thüringische Tentaculiten. Zeitschrift der Deutschen Geologischen Gesellschaft 6, 275-290.

RuAN, Y.P. 1981. Devonian and earliest Carboniferous Ammonoids from Guangxi and Guizhou. Memoirs of the Nanjing Institute of Geology \& Paleontology 15, 1-152. [in Chinese]

RUAN, Y.P. 1996. Zonation and distribution of the early Devonian primitive ammonoids in South China, 104-112. In WANG, H.-Z. \& WANG, X.-L. (ed.) Centennial Memorial Volume of Prof. Sun Yunzhen: Paleontology and Stratigraphy. China University of Geosciences Press, Wuhan.

Ruzhencev, V.E. 1957. Phylogeny and systematic of Palaeozoic ammonoids. Byulleten'Moskovskogo obshchestva ispytatelei prirody, novaya seriya, otdel geologicheskiy 31(2), 49-64. [in Russian]

Rzhonsnitskaja, M.A. 1968. Opisanija brachiopod/Biostratigraphija Devona jukrain Kiuselkogo bassenie. T. 2, v. 1. Pentamerida I Atrypida. 269 pp. Niedra. [in Russian]

SCHLAGER, W. 1981. The paradox of drowned reefs and carbonate platforms. Geological Society of America, Bulletin 92, 197-211.

DOI 10.1130/0016-7606(1981)92<197:TPODRA >2.0.CO;2

Scotese, C.R. 2001. Digital Paleogeographic Map Archive on CD-Rom, Paleomap Project. Arlington, Texas. http://www. scotese.com

SHEN, Y.T. 1975. Discovery of primitive ammonoids from Nandan of Guangxi and its stratigraphic significance. Professional Papers in Stratigraphy and Paleontology 1, 86-104. [in Chinese]

Shimansky, V.N. 1951. Question of Upper Palaeozoic straight cephalopods evolution. Akademia Nauk SSSR Doklady 79, 867-870. [in Russian]

Steinmann, G. \& Döderlein, L. 1890. Elemente der Paläontologie. 848 pp. Engelmann, Leipzig.

Tonarová, P., Vodrážková, S., Ferrová, L., Puente, G.S. de la, Hints, O., FrÝda, J. \& Kubajko, M. 2017. Palynology, microfacies and biostratigraphy across the Daleje Event (Lower Devonian, lower to upper Emsian. new insights from the offshore facies of the Prague Basin, Czech Republic. Palaeobiodiversity and Palaeoenvironments 97, 419-438. DOI 10.1007/s12549-017-0274-3

Truyols-Massoni, M. 1999. La Edad de las Capas con Mimosphinctes en el Devónico de la Cordillera Cantábrica (NW de España). Trabajos de Geología 21, 377-384.

Verneuil, E. DE 1850. Note sur les fossiles du distrikt de Sabero (Leon). Bulletin de la Société géologique de France 7, 155-186.

Windley, B.F., Alexeiev, D., Xiao, W., Kröner, A. \& Badarch, G. 2007. Tectonic models for accretion of the Central Asian Orogenic Belt. Journal of the Geological Society 164, 31-47. DOI 10.1144/0016-76492006-022

WitTMER, J.M. \& MilLeR, A.I. 2011. Dissecting the global diversity trajectory of an enigmatic group: The paleogeographic history of tentaculitoids. Palaeogeography, Palaeoclimatology, Palaeoecology 312, 54-65. DOI 10.1016/j.palaeo.2011.09.009

Xian, S., Wang, S., Zhou, X., Xiong, J. \& Zhou, T. 1980. Nandan typical stratigraphy and paleontology of Devonian in South China. Guizhou People's Publishing House (Guyang) 1-161, 48 pls. [in Chinese]

Yatskov, S.V. 1990. The oldest ammonoid family, the Anetoceratidae. Paleontologicheskii Zhurnal 1990, 25-32. [in Russian]

Yolkin, E.A., Kim, A.I. \& Talent, J.A. (eds) 2008. Devonian Sequences of the Kitab Reserve area. Field Excursion Guidebook, Internat. Conf. "Global Alignments of Lower Devonian Carbonate and Clastic Sequences" (SDS/IGCP 499 Project joint field meeting). 97 pp. Publishing House of SB Ras, Novosibirsk.

Yolkin, E.A., Kim, A.I., Weddige, K., Talent, J.A. \& House, M.R. 1997. Definition of the Pragian/ Emsian State boundary. Episodes 20(4), 235-240.

Yu, C.M. \& RuAn, Y.P. 1988. Proposal and comment on the definition of the Emsian. Devonian of The World, Vol. III: Paleoecology and biostratigraphy. Canadian Society of Petroleum Geologists Memoir 14, 179-191.

ZitTel, K.A. von 1881-1885. Handbuch der Palceontologie. I. Abtheilung. Palceozoologie. II. Band. Mollusca und Arthropoda. 893 pp. Verlag R. Oldenbourg, München \& Leipzig. 